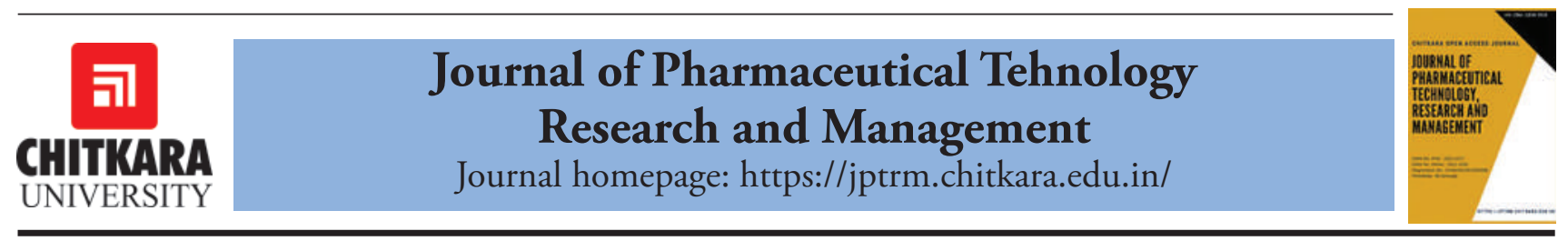

\title{
Evaluation of Ginger Oleoresin in Carbon Tetrachloride Induced Hepatotoxicity in Rats
}

Ravinder Khatri*, Kashish Bhardwaj, Akshay Sharma, Srijana Tamang, Kiran, Umesh Chettri and Arvind Sharma ${ }^{1}$

${ }^{1}$ Assistant Professor Shiva Institute of B. Pharmacy, Bilaspur, Himachal Pradesh, India

*Email: khatri.ravinder07@gmail.com

\section{ARTICLE INFORMATION}

Received: June 05, 2018

Revised: Aug. 10, 2018

Accepted: Oct. 14, 2018

Published online: Nov. 2, 2018

Keywords:

Ginger oleoresin, hepatotoxicity

DOI: $10.15415 /$ jptrm.2018.62007

\section{ABSTRACT}

\begin{abstract}
The present study evaluated the hepatoprotective activity of ginger oleoresin against Carbontetrachloride induced liver toxic damage in rats. Rats were divided into six groups. Hepatotoxicity was induced by the administration of a single intraperitoneal dose $(2 \mathrm{ml} / \mathrm{kg})$ of Carbontetrachloride in experimental rats. Post-treatment with Ginger oleoresin at 300 and $600 \mathrm{mg} / \mathrm{kg}$ dose given by oral routewas carried out to find their protective effectsagainst carbontetrachloride induced hepatic injury. Biochemical parameterfor oxidative stress, inflammation and lipid profile along with genotoxicity and histological changes in rat serum and liver were studied. Silymarin was used as standard hepatoprotective agent. Extracted oleoresin dose dependently provided hepatoprotective effects.The hepatoprotective action of ginger oleoresin may be related to its free radical scavenging,anti-inflammatory and hypolipidemic activity and concluded to be partly mediated by its active constituent's 6-gingerol, shogaol and zingerone. -phosphate; $\mathrm{CCl}_{3}{ }^{*}$, Trichloromethyl free radical; $\mathrm{CCl}_{3} \mathrm{OO}$, Trichloromethyl peroxy radical; ROS, Reactive oxygen species; iNOS, inducible nitric oxide synthase; NO, Nitric oxide, VLDL, Very low density lipoprotein.
\end{abstract}

\section{Introduction}

Liver is the largest gland of body that plays a pivotal role in regulating various physiological processes in the body such as metabolism, secretion and storage. Hepatotoxicity is a term that indicates damage to the cells, tissues, and structure or liver functions. Currently, millions of people are suffering from hepatic damage known to be induced by alcohol, chemicals, and drugs, infections, and immune response (Al-Harbi et al., 2014). Genetic condition modifies susceptibility to various types of causative factors (Bose et al., 2011).Chemicals, in the form of some drugs such as paracetamol, and antitubercular drugs (isoniazid, rifampicin), toxic compounds like carbontetrachloride $\left(\mathrm{CCl}_{4}\right)$, thioacetamide, dimethylnitrosamine, D-galactosamine/ lipopolysaccharide, gamma radiations, cadmium and arsenic heavy metals, mycotoxin (aflatoxin) are unquestionablyvarious risk factors for hepatic injury (Deepa et al., 2013; Domenicali et al., 2009; Larson et al., 2005).

Carbontetrachloride $\left(\mathrm{CCl}_{4}\right)$ is a clear, colorless, volatile, heavy and noninflammable liquid. (Deepa et al., 2013; Domenicali et al., 2009; Larson et al., 2005; Alkreathy et al., 2014) $\mathrm{CCl}_{4}$ is a lipophillic molecule metabolized in liver and spread easily in the lipid compartments of the body. $\mathrm{CCl}_{4}$ is a well-known hepatotoxin or classic model used extensively to investigate the hepatotoxicity in animals by initiating lipid peroxidation (Harbi et al., 2014; Weber et al., 2013; Recknagel et al., 1989). Lipid peroxidation induce membrane disintegration of liver hepatocytes, which in turn increases the release of cytosolic enzymes such as aspartate aminotransferase (AST), alanine aminotransferase (ALT) and alkaline phosphatase (ALP) (Suzek et al., 2015; Mohamed et al., 2014). $\mathrm{CCl}_{4}$ also causes the activation of immune system through the infiltration of inflammatory cells to the site of injury, responsible for the release of pro-inflammatory cytokines such as tumor necrosis factor- $\alpha$ (TNF- $\alpha)$, interleukin- 6 (IL-6) and c-reactive protein (CRP), which further enhance hepatotoxicity through repeated cycle of inflammation (Mohamed et al., 2001a). Administration of $\mathrm{CCl}_{4}$ increased triglycerides (TG), total cholesterol (TC), low density lipoprotein (LDL), whereas lowered the high density lipoprotein (HDL) (Boll et al., 2001a; Andritoiu et al., 2014). $\mathrm{CCl}_{4}$ induced hepatotoxicity lead toaccumulation of $\mathrm{Ca}^{2+}$ in mitochondria, activate many membrane damaging enzymes, causes disruption of mitochondrial metabolism, decreased ATP synthesis and damage micro-filaments that support cell structure(Deepa et al., 2013; Nicotera et al., 1990). Free radicals of $\mathrm{CCl}_{4}$ induced an increase in the number of Agyrophillic nucleolar organizer region (AgNORs) and enhance activity of telomerase enzyme hepatic architecture (Khanna et al., 2003). $\mathrm{CCl}_{4}$ caused various histological 
changes to the liver, including cell necrosis, change in hepatic architecture, Kupffer cell hyperplasia, central vein congestion, inflammation, fatty changes, infilteration of the liver by lymphocytes and hydropic degeneration of hepatic cells is common (Moreira et al., 2014; Al-Sayed et al., 2014).

A flavonoligan mixture of milk thistle, Silymarin (Silybum marianum), is an vital herbal hepatoprotective drug (Abenavoli et al., 2010). Altered cytoplasmic membrane architecture of Silymarin prevented the penetration of hepatotoxic substances, such as carbon tetrachloride, thioacetamide and D-galactosamine, into cells (Abenavoli et al., 2010; Basiglio et al., 2009). Hepatoprotective effects of silymarin are due to several mechanisms including antioxidation, membrane stabilization, immunomodulation, inhibition of lipid peroxidation, anticarcinogen, stimulated protein synthesis and enhanced liver detoxification (Kim et al., 2009; Pradhan et al., 2006; Lieber et al., 2003; Skottova et al., 1999; Luper 1998). Ginger oleoresin also known as gingerin, is widely used herbal remedies obtained by percolating the powdered rhizomes of Zingiber Officinale, which is belonging to the family of Zingiberaceae (Harimurtia et al., 2011). Oleoresin ginger is dark golden brown viscous oil. It consists of essential oils, organic soluble resins and other non-volatile pungent components, which comprised homologous series of phenolic ketones such as gingerols, shogaols and zingerone (Singh et al., 2005; Deline, 1985). These components have reported antioxidant, anti-inflammatory effects, antitumorogenic, antipyretic, antimicrobial cardiotonic, analgesic and antitussive effects (Kumar et al., 2014; Huetal, 2012; Dugasani et al., 2010; Singh et al., 2009; Young et al., 2005; Shin et al., 2005). 6-gingerol was effective in preventing hepatic and renal damage in typeII diabetic $\mathrm{db} / \mathrm{db}$ mice by reducing oxidative stress (Singh et al., 2009). 6-Gingerol-rich fraction lowers total bilirubin and further restores ALT, AST, ALP, and gamma glutaryl transpeptidase (GGT) enzymes the sensitive indicators of hepatocellular damage and dysfunction (Salihu et al., 2016; Sabina et al., 2011). 6-gingerol decreased significantly liver weight index and restore the levels of triglycerides, total cholesterol and free fatty acid in the plasma and liver, which may be the primary protective mechanism exerted by the compound in high fat diet fed hamsters (Tzeng et al., 2015). 6-Shogoal was comparatively more significant in decreasing the hepatic malondialdehyde (MDA) than 6 gingerol possibly due to its dominant antioxidant property. 6-Shogaol is a, 5- lipoxygenase inhibitor (Flynn et al., 1986), contributed to the increased intrahepatic vascular resistance of the cirrhotic rat liver which resulted in prevention from hepatotoxin induced necroinflammatory injury (Titos et al., 2005; Graupeara et al., 2002). 6-Shogoal exhibited a significant hepatoprotective activity by reducing serum activities of AST, ALT and ALP, in to diclofenac sodium intoxicated rats (Alqasouami et al., 2011). Zingerone was found as a hepatoprotective agent due to its free radicals scavenging and anti-inflammatory ability (Kumar et al., 2014; Shin et al., 2005). Zingerone prevents lipid peroxidation in rat liver microsomes (Reddy and Lokesh, 1992). Therefore ginger oleoresin can be used for developing new drugs to treat drug/chemical-induced liver toxicity.

\section{Materials and Methods}

\subsection{Animals}

Wistar albino rats of either sex (weighing 130-300g) procured from the 'Institutional animal house' was employed in the studies. The animals were kept in polyacrylic cages with wire mesh top and soft bedding. Animals were housed under standard environmental conditions $12 \mathrm{~h}$ light and dark cycle and maintained with free access to water and a standard laboratory diet. The experimental protocol was approved by Institutional Animal Ethics Committee (IAEC) IAEC/ SIBP/14/CR-010 as per the guidelines of committee for the purpose of control and supervision of experiments on animals (CPCSEA), Government of India. Animals were acclimatized to laboratory conditions prior to experimental work.

\subsection{Drugs and Chemicals}

Ginger oleoresin from Dayal food products (Indore, India) and Silymarin from Tejkamal Pharmaceuticals Pvt. Ltd. (Bangalore) were used in the study. ATP (Adenosine-triphosphate) was purchased from Sigma-Aldrich, St (Louis, MO, USA). Carbon tetrachloride, Thiobarbituric acid, 5,5-dithio-bis(2-nitrobenzoic acid) (DTNB) and Silver Nitrite $\left(\mathrm{AgNO}_{3}\right)$ were purchased from Otto ChemikaBiochmica (Mumbai, India). All other solvents and chemicals used for experimental work were of analytical grade.

\subsection{Experimental Design}

In the present study, rats were randomly divided into group of six having six animals in each group. Intra-peritoneal (i.p.) administration of a single dose of $2 \mathrm{ml} / \mathrm{kg} \mathrm{CCl}$ was used to induce hepatic injury in rats . Silymarin $(100 \mathrm{mg} /$ $\mathrm{kg}$, p.o.) was used as a reference standard. $300 \mathrm{mg} / \mathrm{kg}$ and $600 \mathrm{mg} / \mathrm{kg}$ doses of ginger oleoresin were dissolved in $1 \%$ gum acacia and administered orally in wistar rats. The experimental design for study was as follows: Group 1 served as normal healthy control rats. Group 2 injected with $\mathrm{CCl}_{4}$ $\left(2 \mathrm{ml} / \mathrm{kg}\right.$ i.p.). Group $3 \mathrm{CCl}_{4}$ co-administered with silymarin drug $(100 \mathrm{mg} / \mathrm{kg}$ p.o.).Group 4 was normal healthy rat administered ginger oleoresin $(600 \mathrm{mg} / \mathrm{kg}$ p.o. $)$. Groups 5 and $6 \mathrm{CCl}_{4}$, co-administered with ginger oleoresin $(300 \mathrm{mg} /$ $\mathrm{kg}$ and $600 \mathrm{mg} / \mathrm{kg}$ p.o.) respectively. 


\subsection{Assessment of Weight}

\subsubsection{Estimation of body weight}

The body weight of rats belonging to different groups were accessed on first day and final day of experimental protocol and compared for the changes.

\subsubsection{Estimation of liver weight}

The liver tissue in all groups was taken out after scarifying animals on $15^{\text {th }}$ day. The tissue was cleaned with saline, blotted dry, placed on aluminum foil and weighed on electronic balance.

\subsubsection{Estimation of relative liver weight}

The remnant, regenerated liver was eviscerated and weighed (A) and total body weight (B) was measured at the time of sacrifice. The acquired data was expressed as percentage of the ratio between remnant liver weight, divided by the total body weight times 100 .

Liver/ Body Weight Ratio $(\%)=\mathrm{A} / \mathrm{B} \times 100$

\subsection{Biochemical Parameters}

\subsubsection{Preparation of serum and liver homogenate}

On $15^{\text {th }}$ day of protocol schedule, animal were weighed and sacrificed after $24 \mathrm{~h}$ of the last treatment. $3 \mathrm{ml}$ of blood sample from each animal was taken. The collected blood was allowed to clot for 15 minutes. At $3000 \mathrm{rpm}$ samples were centrifuged for $15 \mathrm{~min}$ and serum was used for biochemical analysis. Liver was removed and weighed andthen perfused in ice-cold saline solution. A $10 \%(\mathrm{w} / \mathrm{v})$ tissue homogenates was prepared in $0.1 \mathrm{M}$ phosphate buffer $(\mathrm{pH}$ 7.4). The homogenate was centrifuged at $10,000 \times \mathrm{g}$ for $15 \mathrm{~min}$. Collectedsupernatant was and used for biochemical estimation.

\subsubsection{Assessment of total protein in tissue homogenate}

The protein content was assessed by Biuret method (Nicotera et al., 1990) using diagnostic protein estimation kit. The working reagent containing potassium iodide, potassium sodium tartrate, copper sulphate and sodium hydroxide $(1000 \mu \mathrm{l})$ was added to $20 \mu \mathrm{l}$ standard protein and $20 \mu \mathrm{l}$ sample to prepare standard and test. Blank contains 1000 $\mu \mathrm{l}$ of reagent only. All the tubes were incubated at $37^{\circ} \mathrm{C}$ for $10 \mathrm{~min}$, the absorbance for sandard and test were measured against blank at $546 \mathrm{~nm}$ spectrophotometrically. when treated with cupric ions in alkaline solution protein presents in sample formed a blue color complex and intensity of color is proportional to proteins present in sample.

$$
\text { Total protein concentration }(\mathrm{g} / \mathrm{dL})=\frac{\text { Absorbance of test }}{\text { Absorbance of standard }} 1 \times \text { Concentration of standard }(\mathrm{g} / \mathrm{dL})
$$

\subsubsection{Assessment of Oxidative Stress} 2.5.3.1 Estimation of malondialdehyde (MDA) in tissue
homogenate

Lipid peroxidation assay was carried out by the method of (Habig et al., 1979). ${ }^{41}$ Biomarker Malondialdehyde (MDA) is of lipid peroxidation and reacts with thiobarbituric acid (TBA) to form a pink chromogen.Liver homogenate $(1 \mathrm{ml})$ was mixed with trichloroacetic acid (TCA) $1 \mathrm{ml}(10 \% \mathrm{w} / \mathrm{v})$ was centrifuged at $1850 \mathrm{~g}$ for $15 \mathrm{~min}$ followed by addition of $1 \mathrm{ml}$ of TBA solution $(0.67 \% \mathrm{w} / \mathrm{v})$ to $1 \mathrm{ml}$ of supernatant and was boiled for $45 \mathrm{~min}$. Absorbance was read after cooling at $530 \mathrm{~nm}$ against a blank containing all the reagent except liver homogenate. Standard curve was used to measure the concentration of MDA in the supernatant and results were expressed as MDA equivalents in $\mathrm{nmol} / \mathrm{g}$ liver.

\subsubsection{Estimation of reduced glutathione (GSH) in tissue homogenate}

(Jollow et al., 1974) method was used to estimate reducedglutathione content. $1.0 \mathrm{ml}$ of sample homogenate was precipitated with $1 \mathrm{ml}$ of $(4 \%)$ sulfosalicylic acid. For $1 \mathrm{~h}$ samples were kept at $4^{\circ} \mathrm{C}$ for and then centrifuged at
$1200 \mathrm{~g}$ for $20 \mathrm{~min} .3 .0 \mathrm{ml}$ assay mixture contained $0.1 \mathrm{ml}$ filtered aliquot, $2.7 \mathrm{ml}$ phosphate buffer $(0.1 \mathrm{~mol} ; \mathrm{pH} 7.4)$ and $0.2 \mathrm{ml} 5,5$-dithio-bis (2-nitro benzoic acid) (DTNB) $(100 \mathrm{mmol})$. The yellow color developed was estimated at $412 \mathrm{~nm}$ on spectrophotometer and was expressed as $\mu \mathrm{mol}$ GSH/g tissue.

\subsubsection{Estimation of superoxide dismutase (SOD) in tissue homogenate}

SOD activity was measured by well established method described by (Misra and Frodvich, 1972). Supernatant 0.2 $\mathrm{ml}$ of the liver homogenate was mixed with $0.8 \mathrm{ml} 50 \mathrm{mmol}$ of $\mathrm{pH} 10.4$ glycine buffersfollowed by reaction with addition of $0.02 \mathrm{ml}$ of epinephrine. After $5 \mathrm{~min}$ the absorbance was measured at 480 nmspectrophotometrically. SOD activity was expressed as percent activity.

\subsubsection{Estimation of catalase (CAT) in tissue homogenate}

(Aebi et al., 1974) method was used by measuring the changes in absorbance of a solution of $10 \mathrm{mM} \mathrm{H}_{2} \mathrm{O}_{2}$ in phosphate buffer, $\mathrm{pH}$ 7.0. The decreased absorbance per unit time is a measure of catalase activity. $20 \mu \mathrm{l}$ liver homogenate was added to the cuvette containing $980 \mu \mathrm{l}$ of the substrate 
mixture $\left(0.30 \mathrm{ml}\right.$ of $\mathrm{H}_{2} \mathrm{O}_{2}$ in $50 \mathrm{ml}$ of $0.05 \mathrm{M}$ phosphate buffer, $\mathrm{pH}$ 7.0). Initial absorbance was recorded after $1 \mathrm{~min}$ followed by final absorbance after $6 \mathrm{~min}$. The reaction was estimated at $230 \mathrm{~nm}$, CAT activity was expressed as percent activity.

\subsubsection{Estimation of reduced form of nicotinamide adenine dinucleotide phosphate (NADPH) in tissue homogenate}

Liver homogenate was added to $1.5 \mathrm{ml}$ medium of $(125 \mathrm{mM}$ sucrose, $65 \mathrm{mM} \mathrm{KCl}$ and $10 \mathrm{mM} \mathrm{KOH}, \mathrm{pH} 7.4)$ and centrifuged at $8000 \mathrm{~g}$ for 3 min.Fluorescence of collected supernatant was measured at $450 \mathrm{~nm}$ spectrophotometericlaly. The activity of NADPH was expressed as percent activity (Moreira et al., 2014).

\subsubsection{Estimation of adenosine-tri-phosphate (ATP)}

Aliqutos of homogenate $(1 \mathrm{ml})$ were sonicated immediately in $2 \mathrm{ml}$ of ice cold perchloric acid $(0.1 \mathrm{~N})$ which was used to inactivate ATPases and freezed for 2 hour. Supernatants containing ATP was neutralized with $1 \mathrm{~N} \mathrm{NaOH}$ after centrifugation $\left(3000 \mathrm{~g}, 4^{\circ} \mathrm{C}, 5 \mathrm{~min}\right)$ and adjusted to $\mathrm{pH}$ 6-6.5. The sample was stirred again for $5 \mathrm{~min}$ and placed at ice-bath for $1 \mathrm{hr}$. The absorbance was measured spectrophotometrically at $365 \mathrm{~nm}$ (Ramanathan et al., 2012).

\subsubsection{Assessment of inflammation}

2.5.5.1 Nitrite/ nitrate level estimation in tissue homogenate Nitrite which was accumulated in the supernatant is an indicator of the production of nitric oxide, was determined by colorimetric assay using Greiss reagent $(0.1 \% \mathrm{~N}-(1$-naphthyl) ethylene diamine dihydrochloride, $1 \%$ sulfanilamide and $2.5 \%$ phosphoric acid) as described by (Green et al., 1982). Equal volumes of supernatant and Greiss reagent were mixed and mixture was incubated for $10 \mathrm{~min}$ at room temperature in the dark followed by estimation at $540 \mathrm{~nm}$ spectrophotometrically (Green et al., 1982).

\subsubsection{Estimation of serum C-reactive protein (CRP)}

C-reactive protein (CRP)increases significantly in most of tissue injuries, bacterial and viral infections, inflammation and malignant neoplasia is an acute phase protein present in normal serum. CRP is carried by CRP turbilatex method using CRP kit. The reagents and the photometer (cuvette holder) were maintained by $37^{\circ} \mathrm{C}$. The wavelength was adjusted to $540 \mathrm{~nm}$, temperature $37^{\circ} \mathrm{C}$ and with path length of $1 \mathrm{~cm}$. Instrument was adjusted to zero with

$$
\mathrm{CRP}(\mathrm{mg} / \mathrm{L})=\frac{\left(\mathrm{A}_{2}-\mathrm{A}_{1}\right) \text { sample }}{\left(\mathrm{A}_{2}-\mathrm{A}_{1}\right) \text { calibrator }} \times \text { Calibrator concentration }
$$

distilled water. $5.0 \mu \mathrm{l}$ of serum/Calibrator was mixed with 900ul diluent (Tris buffer $20 \mathrm{mmol} / 1 \mathrm{pH} 8.2$ ) and $100 \mu \mathrm{l} \mathrm{of}$ latex. The absorbance was measured initialy $\left(A_{1}\right)$ and after 2 minutes $\left(A_{2}\right)$ of the sample addition.

\subsubsection{Assessment of lipid profiles}

\subsubsection{Estimation of serum high density lipoprotein (HDL)}

High density lipoproteins includes free and esterified cholesterol, triglycerides, phospholipids and apoproteins A, $\mathrm{C}$ and E. Chylomicrons, LDL and VLDL were precipitated from serum by phosphotungstate in the presence of divalent cations such as magnesium. The HDL cholesterol remains unaffected in the supernatant and is estimated using cholesterol reagent of ERBA diagnostic kit.

Instrument was adjusted to zero with blank $(1000 \mu \mathrm{l}$ cholesterol working reagent mixed with $50 \mu$ l of distilled water). $50 \mu \mathrm{l}$ of serum/standard was mixed with $1000 \mu \mathrm{l}$ of cholesterol working reagent. Well mixed samples were incubated for 10 $\min$. at $37^{\circ} \mathrm{C}$. The wavelength was adjusted to $505 \mathrm{~nm}$. The absorbance of standard and test were measured as

$$
\text { HDL Cholesterol }(\mathrm{mg} / \mathrm{dL})=\frac{\text { Absorbance of test }}{\text { Absorbance of Standard }} \times \text { Concentration of standard }(\mathrm{mg} / \mathrm{dL}) \times \text { Dilution factor }
$$

\subsubsection{Estimation of serum triglyceride (TG)}

Elevation of triglycerides has been identified as a risk factor for atherosclerotic disease and liver dysfunctioning. Triglycerides were estimated using reagent of ERBA diagnostic kit. Instrument was adjusted to zero with blank
(1000 $\mu \mathrm{l}$ of working reagent mixed with $10 \mu \mathrm{l}$ of distilled water). $10 \mu \mathrm{l}$ of serum/standard was mixed with $1000 \mu \mathrm{l}$ of working reagent. Well mixed samples were incubated for $10 \mathrm{~min}$ at $37^{\circ} \mathrm{C}$. The absorbance of standard and each test at $505 \mathrm{~nm}$ was measured spectrophotometrically against blank.

$$
\text { Triglycerides }(\mathrm{mg} / \mathrm{dL})=\frac{\text { Absorbance of test }}{\text { Absorbance of standard }} \times \text { Concentration of standard }(\mathrm{mg} / \mathrm{dL})
$$

\subsubsection{Estimation of serum total cholesterol (TC)}

To evaluate risk of the coronary arterial occlusion, atherosclerosis, myocardial infarction, liver function, biliary function, intestinal absorption, thyroid function and adrenal disease serum cholesterol levels measurement are useful. Cholesterol levels were estimated using reagent of ERBA 
diagnostic kit. Instrument was adjusted to zero with blank

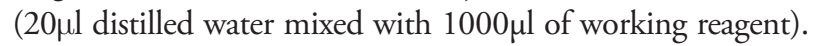
$20 \mu \mathrm{l}$ of serum/standard was mixed with $1000 \mu \mathrm{l}$ of working reagent and incubated at $37^{\circ} \mathrm{C}$ for 10 minutes. Aspiration of both blank, standard and test was performed followed by measurement of absorbancespectrophotometrically at $505 \mathrm{~nm}$.

$$
\text { Cholesterol }(\mathrm{mg} / \mathrm{dL})=\frac{\text { Absorbance of test }}{\text { Absorbance of standard }} \times \text { Concentration of standard }(\mathrm{mg} / \mathrm{dL})
$$

\subsubsection{Assessment of liver marker enzymes in serum}

\subsubsection{Estimation of serum enzyme aspartate aminotrans- ferase (AST)}

AST is present in large amounts in. Increased levels of AST are associated with liver disease or damage, myocardial infarction, muscular dystrophy and cholecystitis as they are abundant in liver, renal, cardiac and skeletal muscle tissue. AST was estimated using reagent of ERBA diagnostic kit. Instrument was set as zero with distilled water. $100 \mu \mathrm{l}$ of serum was mixed with $1000 \mu \mathrm{l}$ of working reagent. Absorbance of each test was measured after every minute for four minute after proper mixing.

Activity of AST $(\mathrm{IU} / \mathrm{L})=\Delta$ Absorbance/min $\times 1768$ (factor)

$\Delta$ Absorbance $=$ Change in Absorbance

Factor $=1768$

\section{5.7.2 Estimation of serum enzyme alanine aminotrans- ferase (ALT)}

ALT is present in high concentration in the liver and increased levels are generally a result of primary liver diseases such as cirrhosis, carcinoma, viral or toxic hepatitis and obstructive jaundice. ALT was estimated using reagent of ERBA diagnostic kit. The wavelength was adjusted to $340 \mathrm{~nm}$. Instrument was set at zero with distilled water. $100 \mu \mathrm{l}$ of serum was mixed with $1000 \mu \mathrm{l}$ of working reagent and the absorbance of each test was measured after every minute.

Activity of ALT at $37^{\circ} \mathrm{C}(\mathrm{IU} / \mathrm{L})=(\Delta \mathrm{A} / \mathrm{min}) \times$ Factor $(1768)$

\subsubsection{Estimation of Serum enzyme alkaline phosphatase} (ALP)

Alkaline phosphatase is present in high concentration in the liver, bone, placenta, intestine and certain tumors. Increase in Alkaline phosphatase activity in serum or plasma is related to disease of bone, biliary tract and liver. Alkaline Phosphatase hydrolyses para-nitrophenyl phosphate into paranitrophenol and phosphate, in the presence of magnesium ions in sample. The rate of increase in absorbance of the reaction mixture at $405 \mathrm{~nm}$ due to liberation of paranitrophenol is proportional to the alkaline phosphatase activity. ALP was estimated using reagents of Enzopak diagnostic kit. The wavelength was adjusted to $405 \mathrm{~nm}$. Instrument was adjusted to zero with reagent blank. $20 \mu \mathrm{l}$ of serum was mixed with $1000 \mu \mathrm{l}$ of buffered substrate and the absorbance was measured at 30 , $60,90 \& 120$ seconds at $405 \mathrm{~nm}$.
Alkaline Phosphatase activity $(\mathrm{IU} / \mathrm{L})=(\Delta \mathrm{A} / \mathrm{min})$

$\times$ Factor $(2713)$

\subsubsection{Histopathological studies}

After removal of Liver tissue from the anterior portion of the left lateral lobe it was further subjected to histological analysis. After fixing Liver fragments in a $10 \%$ solution of formaldehyde, they were dehydrated in graduated ethanol (50-100\%), cleared in xylene and finally embedded in paraffin. 4-5 $\mu \mathrm{m}$ hepatic sections were analyzed by light microscopy with a magnification of $400 \times$ after staining with hematoxylin and eosin (H\&E) using standard techniques.

\subsubsection{Genotoxicity study}

2.5.9.1 AgNORs count

Silver staining technique by well-established method by (Trere et al., 1996) was performed on dried slides. Unstained fixed and dried slides were treated with one drop of colloidal solution ( $2 \%$ gelatin and $1 \%$ formic acid) and two drops of $50 \% \mathrm{AgNO}_{3}$ and were incubated at $35^{\circ} \mathrm{C}$ for about 8-12 min. The progressive staining was followed under microscope to get golden colored nuclei and brown/black NORs. After washing slides with distilled water it was further treated with $1 \%$ sodium thiosulphate for $1 \mathrm{~min}$ at room temperature to stop the reaction, and washed in tap water. Number of AgNORs was counted per cell. Counting was performed, using oil immersion at 100X. Areas with minimal cell overlap and no artifact were demarcated for counting. The appearance of black dots within the green colored nuclear background. Dots were defined as discrete homogenous silver precipitates with well-defined edges.

\subsubsection{Statistical analysis}

All the values are expressed as mean \pm S.D. Data obtained from various groups was assessed at GraphPad Prism 5 and statistically analyzed using one way ANOVA, followed by Tukey test for comparison of all the groups. A 'P' value of less than 0.001 was considered statistically significant.

\section{Results}

\subsection{Effect of Ginger Oleoresin on Body Weight, Liver Weight and Relative Liver Weight}

Administration of $\mathrm{CCl}_{4}$ significantly reduced $(\mathrm{p}<0.0001)$ the body weight, while increased $(\mathrm{p}<0.0001)$ the liver 
weight of rats, when compared to normal group. Post treatment with ginger oleoresin at $300 \mathrm{mg} / \mathrm{kg}$ and $600 \mathrm{mg} /$ $\mathrm{kg}$ p.o. dose for 14 days significantly ameliorates the changes of body weight, liver weight and relative liver weight, when compared to $\mathrm{CCl}_{4}$ treated group. (Table 1)

Table 1: Effect of Ginger oleoresin on body weight, liver weight and relative liver weight

\begin{tabular}{lcccc}
\hline Treatment & $\begin{array}{c}\text { Body weight } \\
(\mathbf{g})\end{array}$ & $\begin{array}{c}\text { Liver weight } \\
(\mathbf{g})\end{array}$ & $\begin{array}{c}\text { Relative liver weight } \\
(\%) \text { to body weight }\end{array}$ & $\begin{array}{c}\text { Total protein } \\
(\mathbf{g} / \mathbf{d L})\end{array}$ \\
\hline Normal group & $187.00 \pm 8.59$ & $5.67 \pm 0.34$ & $2.74 \pm 0.19$ & $7.45 \pm 1.81$ \\
$\mathbf{C C l}_{4}$ treated group & $139.66 \pm 5.16$ & $6.67 \pm 0.10$ & $4.31 \pm 0.14$ & $3.00 \pm 0.56$ \\
$\begin{array}{l}\text { Silymarin pre-treated } \\
\text { ginger oleoresin, }\end{array}$ & $175.33 \pm 5.16$ & $4.92 \pm 0.42$ & $2.75 \pm 0.23$ & $6.91 \pm 0.74$ \\
$\begin{array}{l}\text { Postreated group -1 } \\
\text { ginger oleoresin }\end{array}$ & $181.83 \pm 2.04$ & $6.25 \pm 0.23$ & $2.94 \pm 0.16$ & $5.50 \pm 0.28$ \\
\begin{tabular}{l} 
Postreated group -11 \\
\hline
\end{tabular} & $196.66 \pm 5.16$ & $6.46 \pm 0.10$ & $2.73 \pm 0.07$ & $8.21 \pm 0.71$ \\
\hline
\end{tabular}

\subsection{Effect of Ginger Oleoresin on Total Protein in Tissue Homogenate}

Administration of $\mathrm{CCl}_{4}$ significantly reduced $(\mathrm{p}<0.0001)$ total protein in liver, when compared to normal rats. Post treatment with ginger oleoresin at the dose $300 \mathrm{mg} / \mathrm{kg}$ and $600 \mathrm{mg} / \mathrm{kg}$ successfully revert $(\mathrm{p}<0.0001)$ the changes caused by $\mathrm{CCl}_{4}$. Ginger oleoresin post treatment attenuate protein level in dose dependent manner with $600 \mathrm{mg} / \mathrm{kg}$ ( $\mathrm{p}<0.0001$ ), when compared to $300 \mathrm{mg} / \mathrm{kg}$ dose. (Table 1 )

\subsection{Oxidative Stress Markers}

Oxidative stress causes the damage by production of free radicals and alteration of antioxidant defence system.

\subsubsection{Effect of ginger oleoresin on malondialdehyde (MDA) in tissue homogenate}

A significant increase $(\mathrm{p}<0.0001)$ in MDA level which is an end product of lipid peroxidation was observed in the liver of $\mathrm{CCl}_{4}$ treated rats, when compared with the normal rats. Post treatment with ginger oleoresin at the dose of $300 \mathrm{mg} /$ $\mathrm{kg}$ and $600 \mathrm{mg} / \mathrm{kg}$ significantly reduced $(\mathrm{p}<0.0001)$ the MDA level in liver, when compared with $\mathrm{CCl}_{4}$ administered rats. The dose dependent effects were observed as ginger oleoresin $600 \mathrm{mg} / \mathrm{kg}$ was found more significant in reducing $(p<0.0001)$ MDA level in the liver as compared to ginger oleoresin $300 \mathrm{mg} / \mathrm{kg}$ dose. (Fig.1)

\subsubsection{Effect of ginger oleoresin on reduced glutathione (GSH) in tissue homogenate}

Reduced GSH is a cellular antioxidant which protect against protection against oxidative stress. Hepatic glutathione levels got significantly reduced $(\mathrm{p}<0.0001)$ in $\mathrm{CCl}_{4}$ intoxicated rats as compared to normal rats. Post treatment with ginger oleoresin at the dose of $300 \mathrm{mg} / \mathrm{kg}$ and $600 \mathrm{mg} / \mathrm{kg}$ restored the GSH levels in hepatic tissues $(\mathrm{p}<0.0001)$ as compared to $\mathrm{CCl}_{4}$ treated group. The dose dependent effects were observed as ginger oleoresin $600 \mathrm{mg} / \mathrm{kg}$ was found more significant in increasing $(\mathrm{p}<0.0001)$ GSH level in the liver as compared to ginger oleoresin $300 \mathrm{mg} / \mathrm{kg}$ dose.(Fig.2)
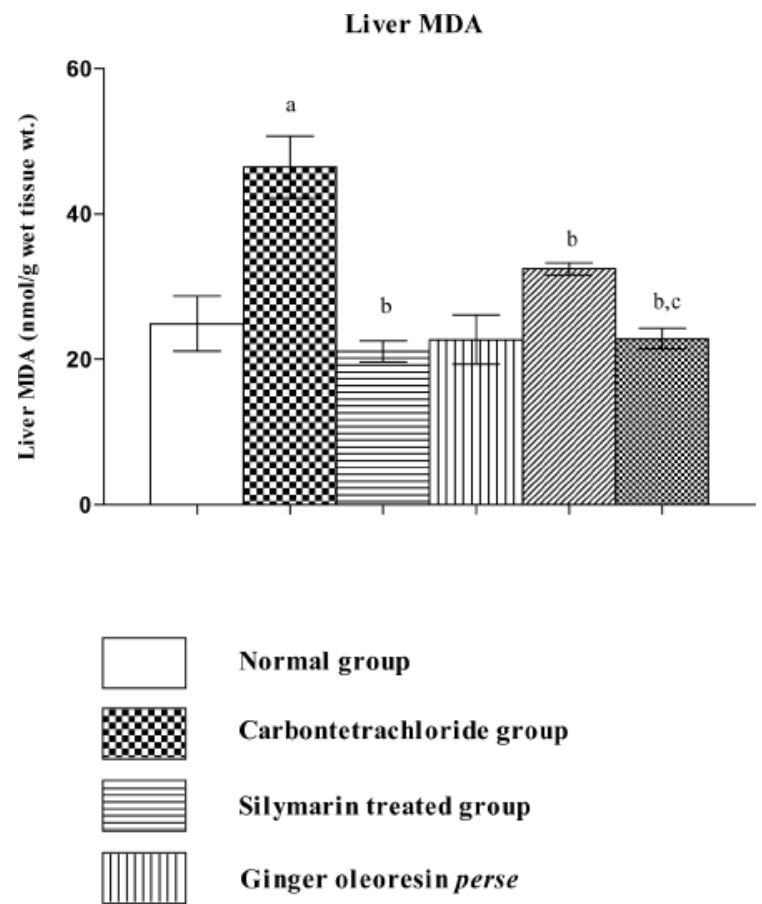

Figure 1: Effect of ginger oleoresin on malondialdehyde (MDA) (nM/g wet tissue wt.) in tissue homogenate

Values were expressed as mean \pm SD. a; $\mathrm{P}<0.0001$ versus Normal group; b $\mathrm{P}<0.0001$ versus Carbontetrachloride group; $\mathrm{p}<0.0001$ versus Ginger oleoresin post treated group-I 

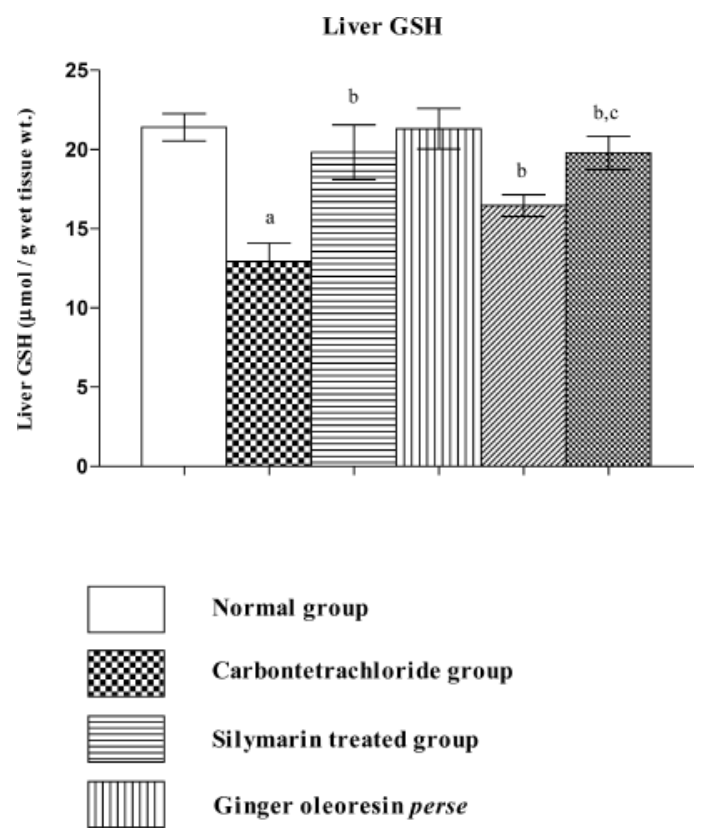

Figure 2: Effect of ginger oleoresin on reduced glutathione (GSH) $(\mu \mathrm{M} / \mathrm{g}$ wet tissue wt.) in tissue homogenate

Values were expressed as mean \pm SD. a; $\mathrm{P}<0.0001$ versus Normal group; b P $<0.0001$ versus Carbontetrachloride group; c $\mathrm{p}<0.0001$ versus Ginger oleoresin post treated group-I

\subsubsection{Effect of ginger oleoresin on superoxide dismutase $(S O D)$ in tissue homogenate}

Antioxidant enzyme SOD plays a key role in detoxifying superoxide anions. $\mathrm{CCl}_{4}$ administration significantly reduced $(\mathrm{p}<0.0001)$ the SOD levels, when compared to normal rats. In post treatment groups, $300 \mathrm{mg} / \mathrm{kg}$ and $600 \mathrm{mg} / \mathrm{kg}$ administration showed significantly increased $(\mathrm{p}<0.0001)$ SOD level, when compared to $\mathrm{CCl}_{4}$ treated group. Dose dependent effects were observed with ginger oleoresin $600 \mathrm{mg} / \mathrm{kg}$ dose. Ginger oleoresin $600 \mathrm{mg} / \mathrm{kg}$ significantly increased $(\mathrm{p}<0.0001)$ SOD levels, when compared to $300 \mathrm{mg} / \mathrm{kg}$ dose. (Fig. 3)

\subsubsection{Effect of ginger oleoresin on catalase (CAT) in tissue homogenate}

Antioxidant enzyme catalasehas capability to detoxify oxidative free radicals. The liver catalase activity significantly decreased $(\mathrm{p}<0.0001)$ in $\mathrm{CCl}_{4}$ intoxicated rats as compared to normal rats. In post treated, $300 \mathrm{mg} / \mathrm{kg}$ and $600 \mathrm{mg} / \mathrm{kg}$ ginger oleoresin groups a significant increase $(\mathrm{p}<0.0001)$ in catalase activity was observed in hepatic tissues, when compared to $\mathrm{CCl}_{4}$ treated group. Ginger oleoresin at the dose of $600 \mathrm{mg} / \mathrm{kg}$ proved its dose dependent effect by significantly increasing $(\mathrm{p}<0.0001)$ catalase activity in rats when compared to $300 \mathrm{mg} / \mathrm{kg}$ dose. (Fig.4)
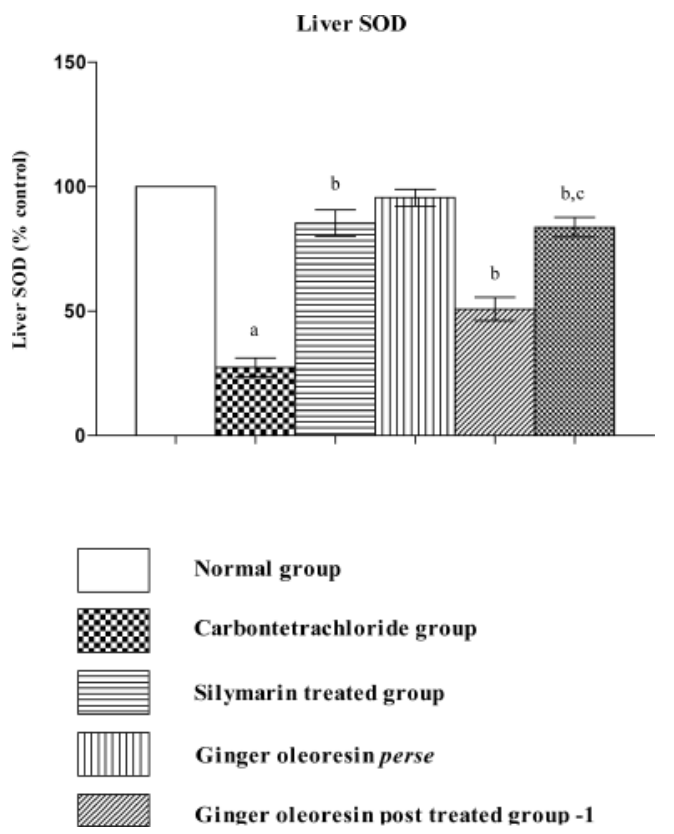

Figure 3: Effect of ginger oleoresin on superoxide dismutase (SOD) (\% control) in tissue homogenate

Values were expressed as mean \pm SD. a; $\mathrm{P}<0.0001$ versus Normal group; b $\mathrm{P}<0.0001$ versus Carbontetrachloride group; $\mathrm{c}$ $\mathrm{P}<0.0001$ Ginger oleoresin post treated group-I

\subsubsection{Effect of ginger oleoresin on reduced nicotinamide adenine dinucleotide phosphate (NADPH) in tissue homogenate}

For biosynthetic reactions NADPH provides the reducing equivalents and oxidation-reduction involved in protecting against the toxicity of ROS. After treatment of rats with $\mathrm{CCl}_{4}$ significantly reduction $(\mathrm{p}<0.0001)$ in the level of NADPH was observed in the liver, as compared with the normal group. Post treatment groups, $300 \mathrm{mg} / \mathrm{kg}$ and $600 \mathrm{mg} / \mathrm{kg}$ ginger oleoresin significantly prevented $(\mathrm{p}<0.0001)$ the changes of NADPH maintaining their levels near to normal range. The dose dependent effect was observed as ginger oleoresin $600 \mathrm{mg} / \mathrm{kg}$ dose was found to be more effective $(\mathrm{p}<0.0001)$ as compared to $300 \mathrm{mg} / \mathrm{kg}$ dose. (Fig. 5)

\subsection{Effect of Ginger Oleoresin on Adenosine Triphosphate (ATP) in Tissue Homogenate}

Adenosine triphosphate (ATP) is a coenzyme used as an energy carrier in the cells. Hepatic ATP levels were significantly reduced $(\mathrm{p}<0.0001)$ in $\mathrm{CCl}_{4}$ intoxicated rats as compared to normal rats. Post treatment with ginger oleoresin at the dose of $300 \mathrm{mg} / \mathrm{kg}$ and $600 \mathrm{mg} / \mathrm{kg}$ significantly attenuated $(\mathrm{p}<0.0001)$ the ATP levels in hepatic tissues as compared to $\mathrm{CCl}_{4}$ treated group. In treatment doses of ginger oleoresin, $600 \mathrm{mg} / \mathrm{kg}$ found to be effective $(\mathrm{p}<0.0001)$, when compared with ginger oleoresin $300 \mathrm{mg} / \mathrm{kg}$ dose. (Fig. 6) 

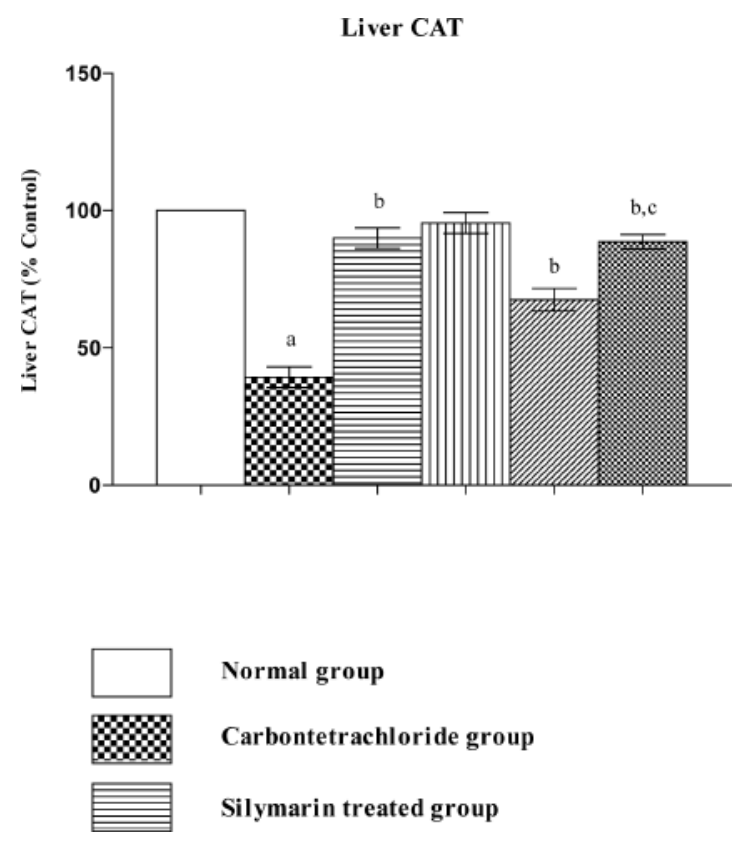

Normal group

Carbontetrachloride group

Silymarin treated group

Figure 4: Effect of ginger oleoresin on catalase (CAT) (\% control) in tissue homogenate

Values were expressed as mean \pm SD. a; $\mathrm{P}<0.0001$ versus Normal group; b $\mathrm{P}<0.0001$ versus Carbontetrachloride group; c $\mathrm{P}<$ $0.0001 \mathrm{Ginger}$ oleoresin post treated group-I
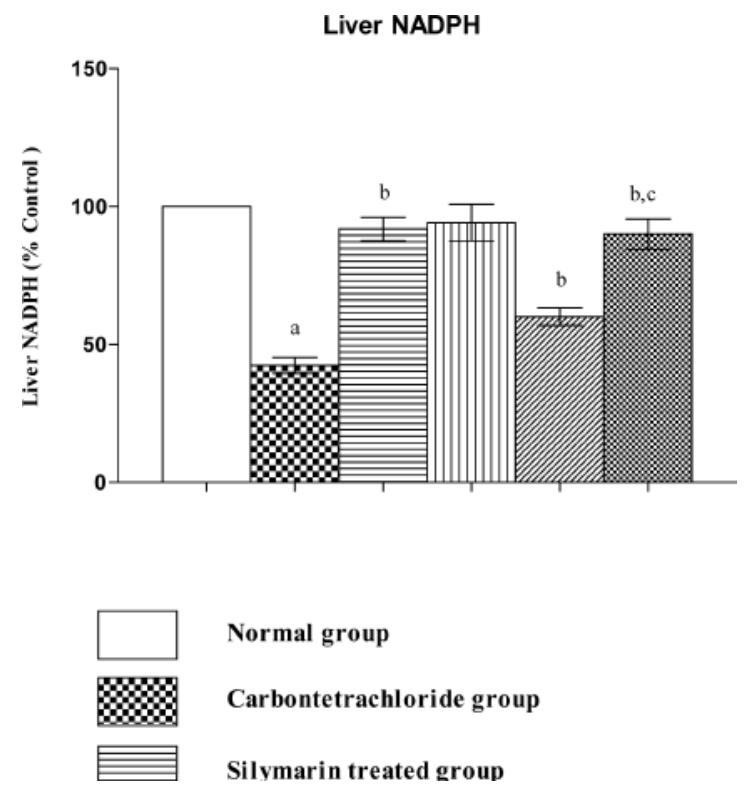

Normal group

Carbontetrachloride group

\section{Silymarin treated group}

Figure 5: Effect of ginger oleoresin on reduced form of nicotinamide adenine dinucleotide phosphate (NADPH) (\% control) in tissue homogenate

Values were expressed as mean \pm SD. a; $\mathrm{P}<0.0001$ versus Normal group; b $\mathrm{P}<0.0001$ versus Carbontetrachloride group; $\mathrm{c}$ $\mathrm{p}<0.0001$ versus Ginger oleoresin post treated group-I
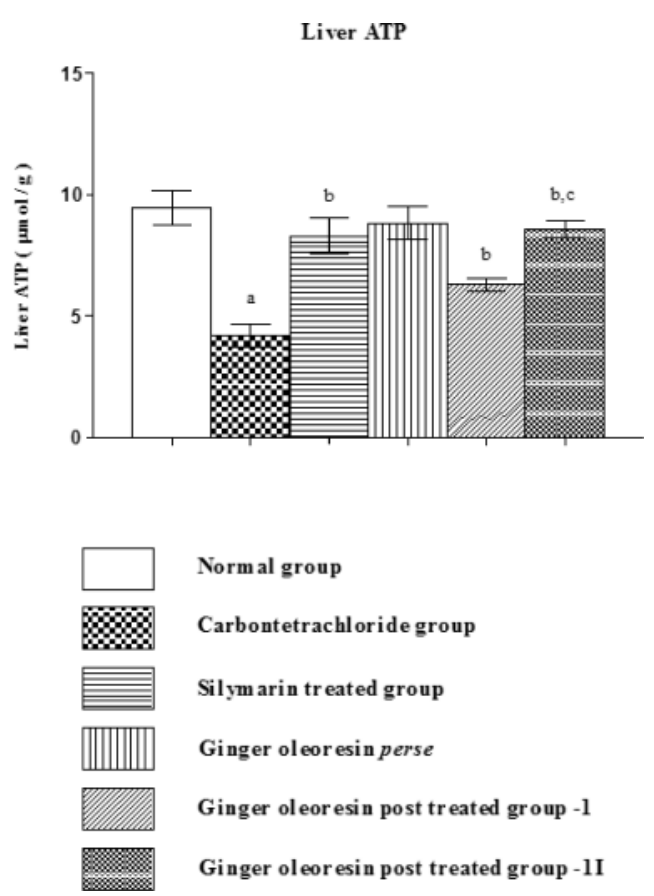

Figure 6: Effect of ginger oleoresin on adenosine-tri-phosphate (ATP) $(\mu \mathrm{M} / \mathrm{g}$ tissue) in tissue homogenate

Values were expressed as mean \pm SD. $a$; $\mathrm{P}<0.0001$ versus Normal group; b $\mathrm{P}<0.0001$ versus Carbontetrachloride group; $\mathrm{c} p<0.0001$ versus Ginger oleoresin post treated group-I

\subsection{Inflammation}

Immune system activation through the infiltration of inflammatory cells at the site of injury resulted in the release of proinflammatory cytokines.

\subsubsection{Effect of ginger oleoresin on nitritel nitrate level in tissue homogenate}

Nitrite accumulation in the supernatant indicates production of nitric oxide. $\mathrm{CCl}_{4}$ administration significantly increased $(\mathrm{p}<0.0001)$ the level of nitrite as compared to normal rats. Post treatment with ginger oleoresin at the dose of $300 \mathrm{mg} / \mathrm{kg}$ and $600 \mathrm{mg} / \mathrm{kg}$ showed significant reduction $(\mathrm{p}<0.0001)$ in the nitrite levels, as compared with $\mathrm{CCl}_{4}$ treated group. The dose dependent effects were observed as ginger oleoresin $600 \mathrm{mg} /$ $\mathrm{kg}$ remarkably reduced $(\mathrm{p}<0.0001)$ the levels of inflammatory marker nitrite, as compared to $300 \mathrm{mg} / \mathrm{kg}$ dose. (Fig. 7)

\subsubsection{Effect of ginger oleoresin on serum $C$-reactive protein (CRP)}

$\mathrm{CCl}_{4}$ administration caused inflammation in rats as assessed in term of significantly elevated serum CRP levels, when compared to normal group. CRP was significantly restored 
$(\mathrm{p}<0.0001)$ in ginger oleoresin post treated at $300 \mathrm{mg} / \mathrm{kg}$ and $600 \mathrm{mg} / \mathrm{kg}$ groups respectively, when compared with $\mathrm{CCl}_{4}$ treated rats. Among treatment doses ginger oleoresin,
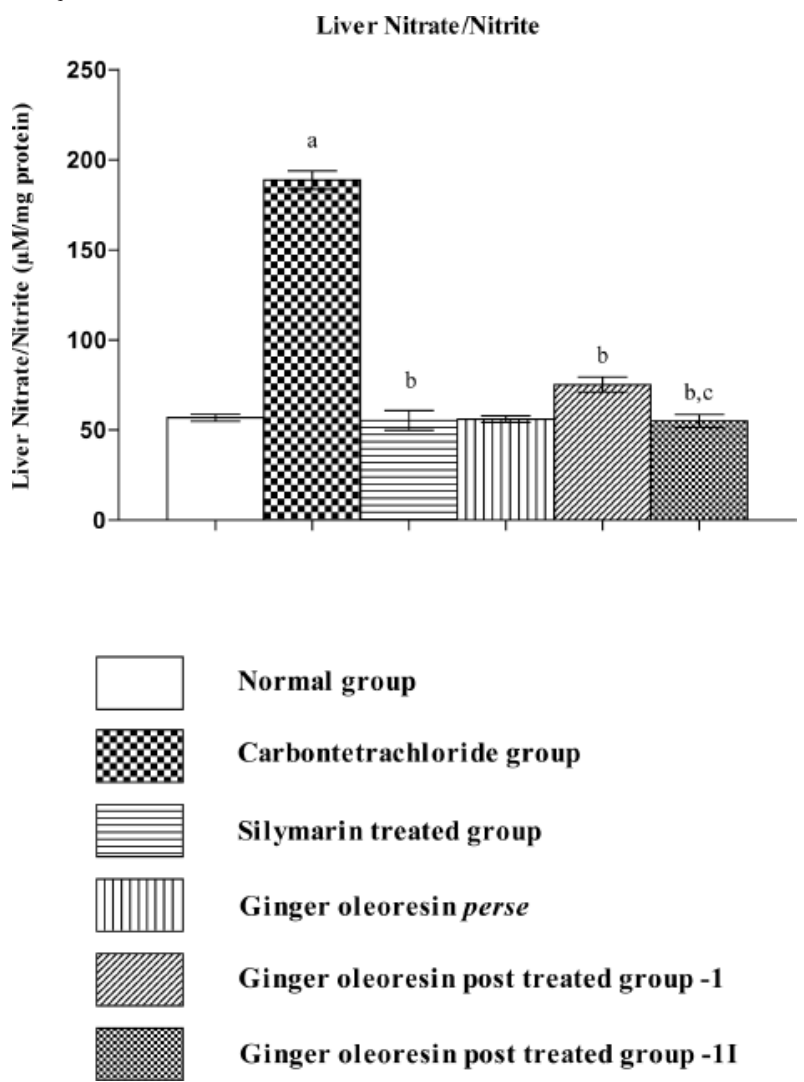

Normal group

Carbontetrachloride group

Silymarin treated group

Ginger oleoresin perse

Ginger oleoresin post treated group -1

Ginger oleoresin post treated group -1I

Figure 7: Effect of ginger oleoresin on nitrate/nitrite $(\mu \mathrm{M} / \mathrm{mg}$ protein) in tissue homogenate

Values were expressed as mean $\pm S D$. a; $\mathrm{P}<0.0001$ versus Normal group; $\mathrm{b} P<0.0001$ versus Carbontetrachloride group; $\mathrm{c} p<0.0001$ versus Ginger oleoresin post treated group-I

\subsection{Lipid Profile}

Lipid synthesis and degradation imbalance impaired oxidation of lipids, failure of triglycerides to move as VLDL resulted in fat accumulation.

\subsubsection{Effect of ginger oleoresin on serum high density lipoprotein $(H D L)$}

Administration of $\mathrm{CCl}_{4}$ significantly reduced $(\mathrm{p}<0.0001)$ serum high density lipoproteins as when compared to normal rats. Reduced HDL cholesterol level was remarkably increased $(\mathrm{P}<0.0001)$ by post treatment with ginger oleoresin $300 \mathrm{mg} / \mathrm{kg}$ and $600 \mathrm{mg} / \mathrm{kg}$ doses. Dose of $600 \mathrm{mg} /$ $\mathrm{kg}$ was found to be more effective ( $\mathrm{p}<0.0001)$, in increasing the HDL levels, when compared with ginger oleoresin $300 \mathrm{mg} / \mathrm{kg}$ dose. (Fig. 9)
$600 \mathrm{mg} / \mathrm{kg}$ dose was found to be more effective $(\mathrm{p}<0.0001)$ in reducing CRP level, when compared with ginger oleoresin $300 \mathrm{mg} / \mathrm{kg}$ dose. (Fig. 8 )
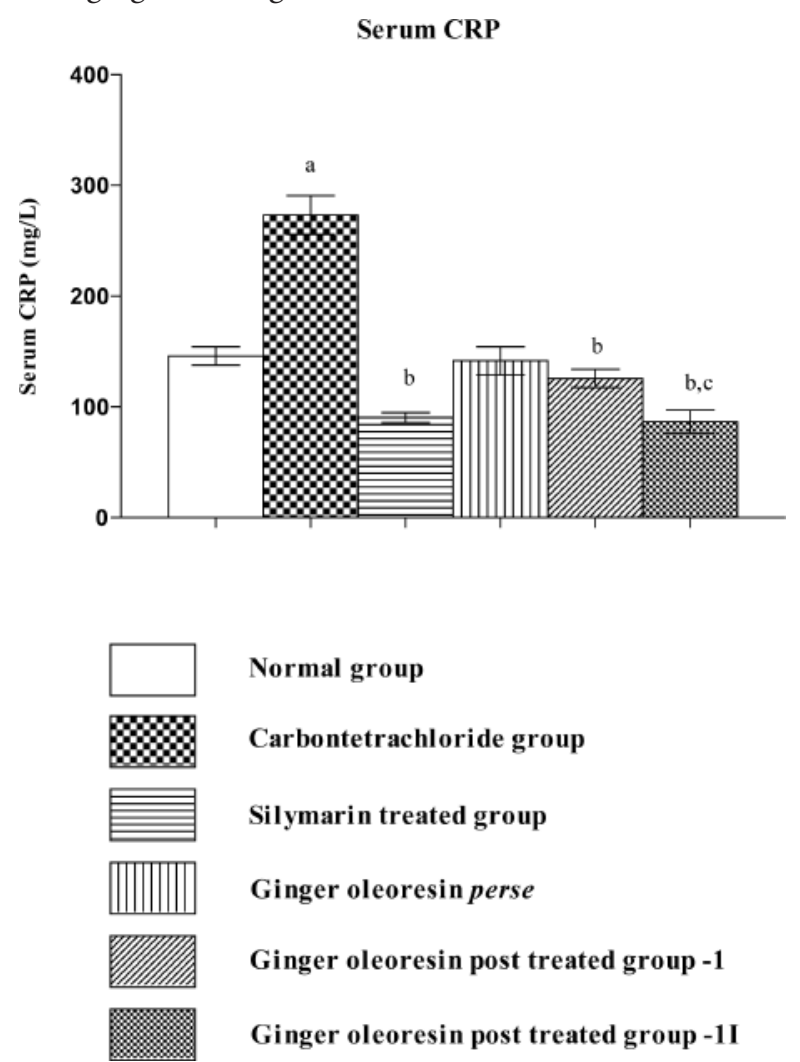

Figure 8: Effect of ginger oleoresin onserum C-reactive protein (CRP) $(\mathrm{mg} / \mathrm{L})$

Values were expressed as mean \pm SD. a; $\mathrm{P}<0.0001$ versus Normal group; $\mathrm{b} \mathrm{P}<0.0001$ versus Carbontetrachloride group; $\mathrm{c} \mathrm{p}<0.0001$ versus Ginger oleoresin post treated group-I

\subsubsection{Effect of ginger oleoresin on serum triglyceride (TG)}

$\mathrm{CCl}_{4}$ caused significant increase $(\mathrm{p}<0.0001)$ in serum triglyceride level, when compared to normal rats. Post treatment with ginger oleoresin at the dose of $300 \mathrm{mg} / \mathrm{kg}$ and $600 \mathrm{mg} / \mathrm{kg}$ appreciably $(\mathrm{P}<0.0001)$ augmented serum triglycerides, when compared with $\mathrm{CCl}_{4}$ treated group. Ginger oleoresin $600 \mathrm{mg} / \mathrm{kg}$ dose significantly reduced $(\mathrm{p}<0.0001)$ triglyceride level as compared to $300 \mathrm{mg} / \mathrm{kg}$ dose. (Fig. 10)

\subsubsection{Effect of ginger oleoresin on serum total cholesterol (TC)}

After treatment with $\mathrm{CCl}_{4}$ serum total cholesterol level in rat serum wassignificantly increased $(p<0.0001)$, when compared to normal rats. Post treatment with ginger oleoresin at the dose of $300 \mathrm{mg} / \mathrm{kg}$ and $600 \mathrm{mg} / \mathrm{kg}$ attenuated 
cholesterol level remarkably ( $\mathrm{P}<0.0001)$, when compared to $\mathrm{CCl}_{4}$ group. Ginger oleoresin $600 \mathrm{mg} / \mathrm{kg}$ administration dose dependently reduced $(\mathrm{p}<0.0001)$ serum total cholesterol level, when compared to $300 \mathrm{mg} / \mathrm{kg}$ dose. (Fig.11)
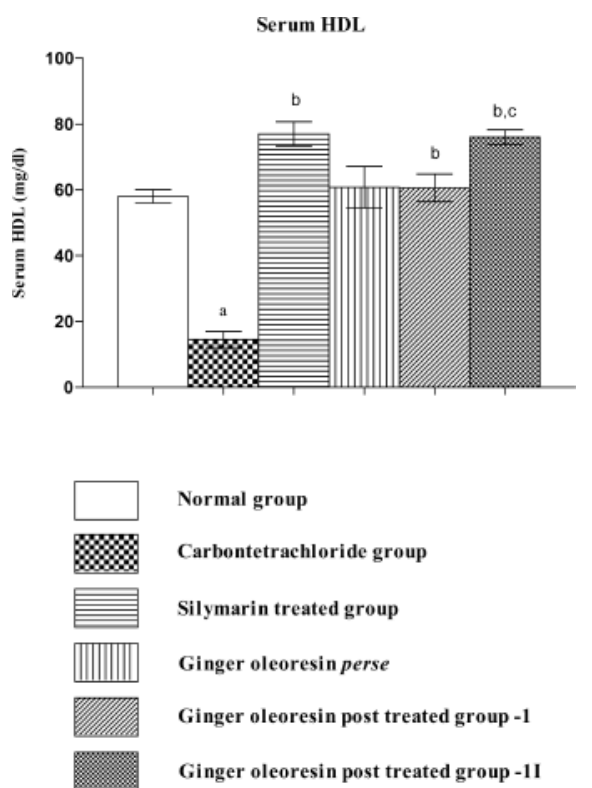

Figure 9: Effect of ginger oleoresin onserum high density lipoprotein $(\mathrm{HDL})(\mathrm{mg} / \mathrm{dL})$

Values were expressed as mean $\pm \mathrm{SD}$. a; $\mathrm{P}<0.0001$ versus Normal group; b $\mathrm{P}<0.0001$ versus Carbontetrachloride group; $\mathrm{c} p<0.0001$ versus Ginger oleoresin post treated group-I
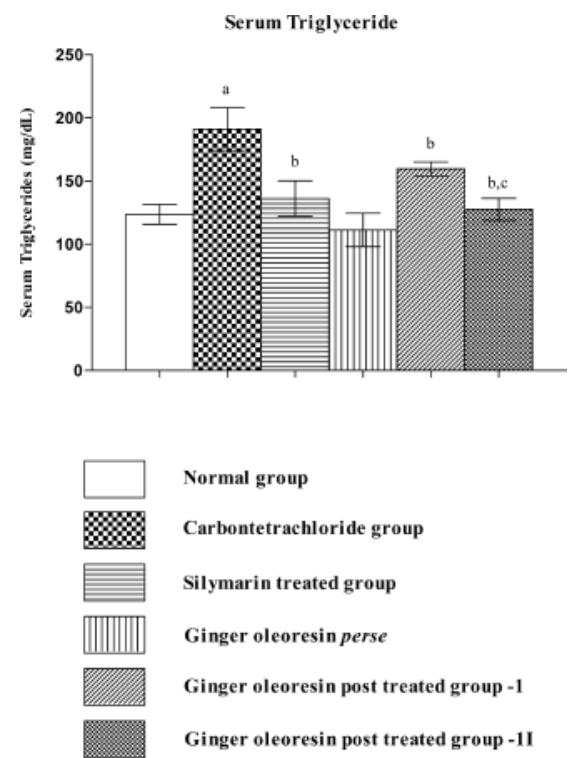

Figure 10: Effect of ginger oleoresin onserum triglyceride (TG) $(\mathrm{mg} / \mathrm{dL})$

Values were expressed as mean $\pm \mathrm{SD}$. a; $\mathrm{P}<0.0001$ versus Normal group; $\mathrm{b} \mathrm{P}<0.0001$ versus Carbontetrachloride group; $\mathrm{c} p<0.0001$ versus Ginger oleoresin post treated group-I

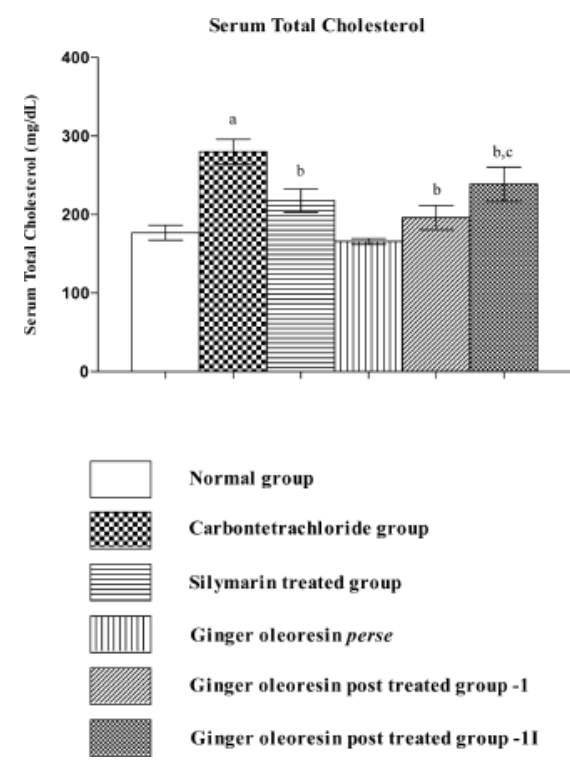

Figure 11: Effect of ginger oleoresin on serum total cholesterol (TC) $(\mathrm{mg} / \mathrm{dL})$

Values were expressed as mean \pm SD. a; $\mathrm{P}<0.0001$ versus Normal group; b $\mathrm{P}<0.0001$ versus Carbontetrachloride group; $\mathrm{c}$ p $<0.0001$ versus Ginger oleoresin post treated group-I

\subsection{Liver marker enzymes}

Increasing oxidative stress accelerated membrane disintegration of liver hepatocytes, which resulted in increased release of cytosolic liver enzymes.

\subsubsection{Effect of ginger oleoresin on serum aspartate aminotransferase (AST)}

Hepatotoxicity was affirmed by a significant increase $(\mathrm{p}<0.0001)$ in AST activity in $\mathrm{CCl}_{4}$ treated group compared with normal group. In treatment groups, $300 \mathrm{mg} / \mathrm{kg}$ and 600 $\mathrm{mg} / \mathrm{kg}$ ginger oleoresin post treatment significantly reduced $(\mathrm{p}<0.0001)$ AST level, and attained levels near the normal range. Among treatment doses of ginger oleoresin, $600 \mathrm{mg} /$ $\mathrm{kg}$ dose exhibited significant reduction $(\mathrm{p}<0.001)$ of AST in serum as compared to $300 \mathrm{mg} / \mathrm{kg}$ dose. (Fig.12)

\subsubsection{Effect of ginger oleoresin on serum alanine aminotransferase (ALT)}

Significant increase in serum ALT $(\mathrm{p}<0.0001)$ in toxic group compared to normal group, indicating liver damage. $\mathrm{CCl}_{4}$ induced elevation of serum enzyme activity, was remarkably prevented $(p<0.0001)$ with post treatment of ginger oleoresin at $300 \mathrm{mg} / \mathrm{kg}$ and $600 \mathrm{mg} / \mathrm{kg}$. Ginger oleoresin $600 \mathrm{mg} / \mathrm{kg}$ post treatment exhibited significant reduction $(\mathrm{p}<0.0001)$ in ALT levels, when compared to ginger oleoresin $300 \mathrm{mg} /$ kg post treatment. (Fig.13) 


\subsubsection{Effect of ginger oleoresin on serum alkaline phosphatase (ALP)}

Elevated serum ALP level $(\mathrm{p}<0.0001)$ in toxic group, when compared to normal group, indicated liver damage. $\mathrm{CCl}_{4}$
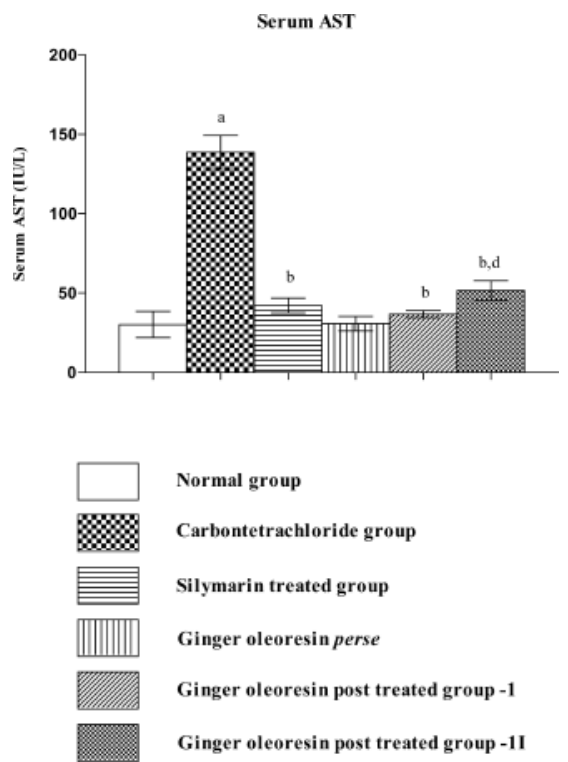

Figure 12: Effect of ginger oleoresin on serum aspartate aminotransferase (AST) (IU/L)

Values were expressed as mean $\pm \mathrm{SD}$. a; $\mathrm{P}<0.0001$ versus Normal group; b $\mathrm{P}<0.0001$ versus Carbontetrachloride group; $\mathrm{d} \mathrm{p}<0.001$ versus Ginger oleoresin post treated group-I
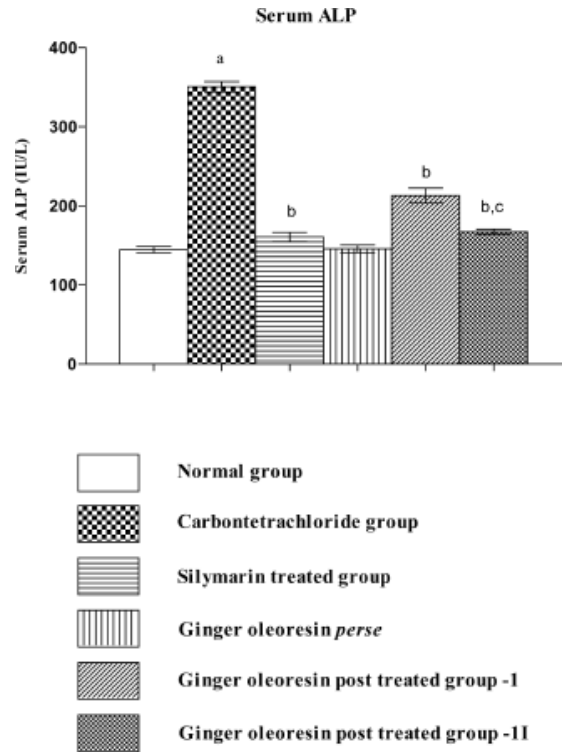

Figure 14: Effect of ginger oleoresin on serum alkaline phosphatase (ALP) (IU/L)

Values were expressed as mean \pm SD. a; $\mathrm{P}<0.0001$ versus Normal group; $\mathrm{b} \mathrm{P}<0.0001$ versus Carbontetrachloride group; $\mathrm{c} \mathrm{p}<0.0001$ versus Ginger oleoresin post treated group-I induced elevation of serum ALP activity, was markedly restored $(\mathrm{p}<0.0001)$ with post treatment of ginger oleoresin $300 \mathrm{mg} / \mathrm{kg}$ and $600 \mathrm{mg} / \mathrm{kg}$ doses. Dose dependent effects were observed with $600 \mathrm{mg} / \mathrm{kg}$ ginger oleoresin.(Fig.14)
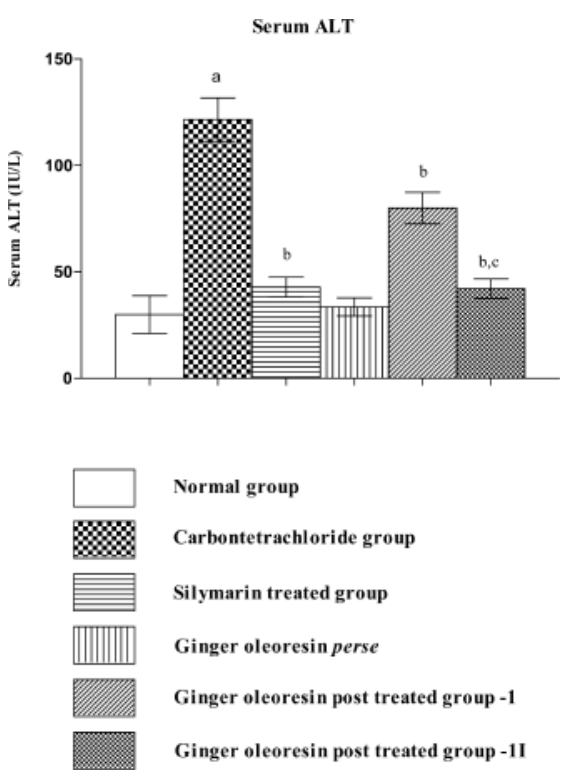

Figure 13: Effect of ginger oleoresin on serum alanine aminotransferase (ALT) (IU/L)

Values were expressed as mean \pm SD. a; $\mathrm{P}<0.0001$ versus Normal group; $\mathrm{b} \mathrm{P}<0.0001$ versus Carbontetrachloride group; $\mathrm{c} \mathrm{p}<0.0001$ versus Ginger oleoresin post treated group-I

\subsection{Effect of Ginger Oleoresin on Rat Liver Morphology}

Administration of $\mathrm{CCl}_{4}$ in ratsshowed change in colour of liver as well as enlargement of liver (Fig. 15B), when compared with normal group (Fig. 15A). Post treatment with ginger oleoresin group restored the change in colour and morphology (Fig. 15D, E).Silymarin being standard hepatoprotective drug showed morphologic changes near to normal (Fig. 15C).

\subsection{Histopathological Changes}

\subsubsection{Effect of Ginger Oleoresin on Liver Histopathology}

$\mathrm{CCl}_{4}$ induced cell injury in livers by was confirmed by histopathological examinations. Photomicrographs of hematoxylin eosin stained liver tissues, normal control hepatocytes had normal architecture (Fig. 16A) as compared in rats treated with $\mathrm{CCl}_{4}$ where severe hepatocyte necrosis, fatty degeneration, inflammatory cells infilteration and hydropic ballooning were observed (Fig. 16B). Post treatment of ginger oleoresin at $300 \mathrm{mg} / \mathrm{kg}$ dose showed less marked effects (Fig. 16D). 600mg/kg dose significantly 
reduced the severity of injury in hepatocells as indicated in (Fig. 16E). Loss of hepatic architecture, marked necrosis, fatty degeneration, inflammatory cell infilteration and hepatocyte ballooning i.e. vacuolization were reduced to significant extent with $600 \mathrm{mg} / \mathrm{kg}$ dose, when compared to
$\mathrm{CCl}_{4}$ group. Post treatment of ginger oleoresin at $600 \mathrm{mg} / \mathrm{kg}$ dose was exhibited more significant results, when compared to $300 \mathrm{mg} / \mathrm{kg}$ ginger oleoresin dose. Silymarin being standard hepatoprotective drug showed histological changes near to normal (Fig. 16C).
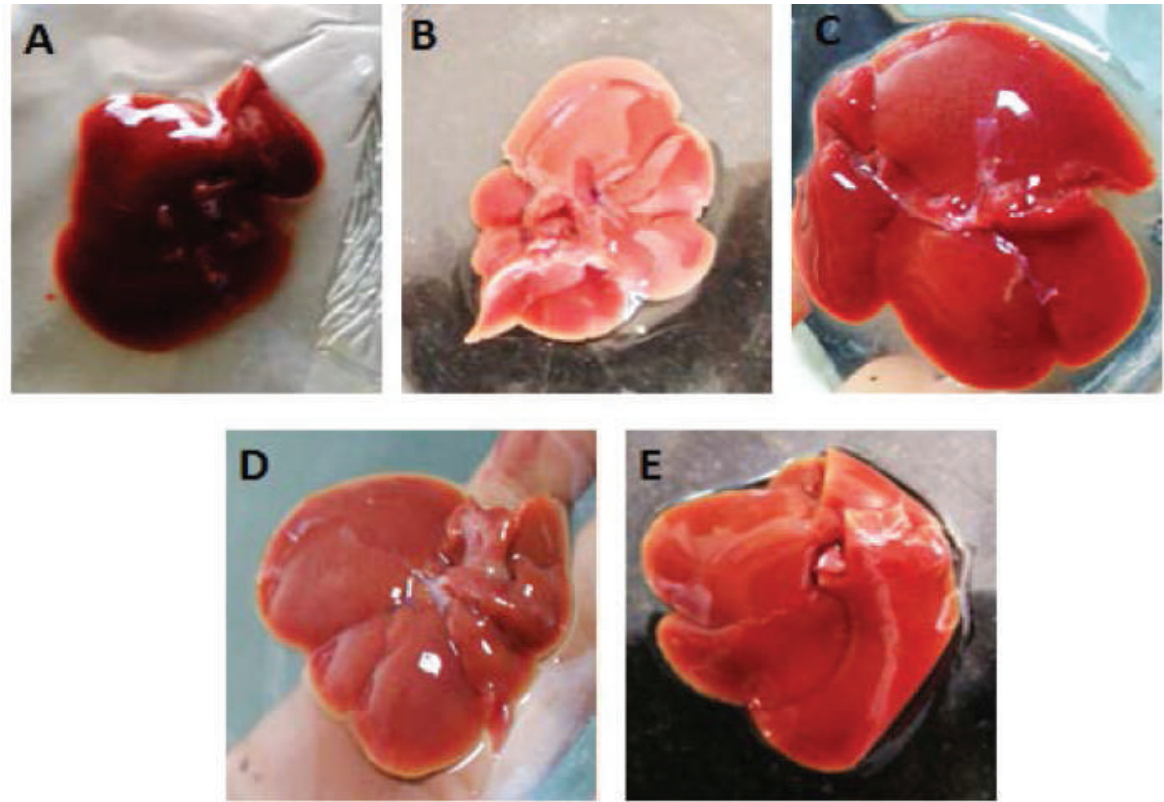

Figure 15: Rat liver morphology

Group I : Normal group

Group III : Silymarin post treated group

Group V : Ginger oleoresin post treated group II
Group II : $\mathrm{CCl}_{4}$-treated group

Group IV : Ginger oleoresin post treated group I
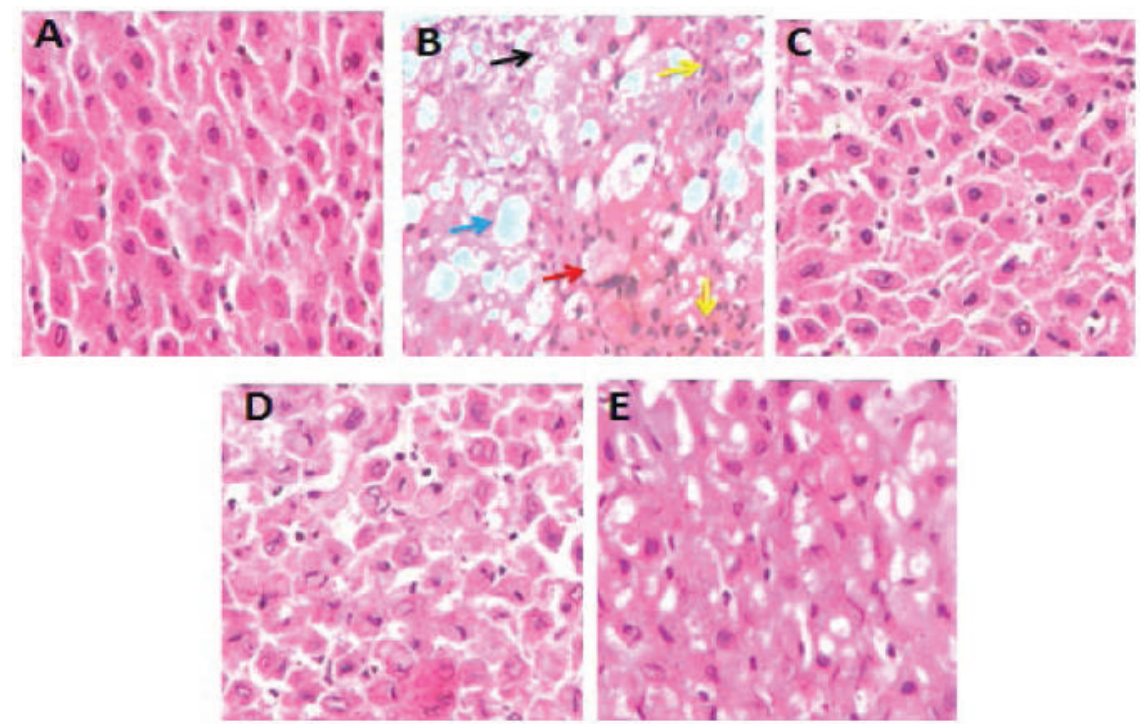

Figure 16: Effect of Ginger oleoresin on Liver Histology.

(A) Group I (Normal group): normal hepatic architecture and normal hepatocyteswith well-preserved cytoplasm, prominent nucleolus. 
(B) Group II ( $\mathrm{CCl}_{4}$-treated group): marked loss of hepatic architecture, marked necrosis $(\longrightarrow)$, fatty degeneration $(\rightarrow)$, Inflammatory cell infilteration $(\longrightarrow)$, hepatocyte ballooning $(\longrightarrow)$.

(C) Group III $\left(\mathrm{CCl}_{4}+100 \mathrm{mg} / \mathrm{kg}\right.$ of Silymarin post treated): showing preserved hepatic architecture.

(D) Group IV $\left(\mathrm{CCl}_{4}+300 \mathrm{mg} / \mathrm{kg}\right.$ of Ginger oleoresin post treated group I): less marked changes

(E) Group V $\left(\mathrm{CCl}_{4}+600 \mathrm{mg} / \mathrm{kg}\right.$ of Ginger oleoresin post treated group II): reversed the changes induced by $\mathrm{CCl}_{4}$. Necrosis $(\longrightarrow)$, fatty degeneration $(\longrightarrow)$, inflammatory cells infilteration $(\longrightarrow)$ and hydropic ballooning $(\longrightarrow)$.

\subsection{Effect of Ginger Oleoresin on Genotoxicity Studies}

\subsubsection{Effect of ginger oleoresin on liver agnor count}

Administraion of $\mathrm{CCl}_{4}$ significantly increased the region of AgNORs (Fig. 17B). Preventive efficacy of ginger oleoresin against $\mathrm{CCl}_{4}$ administration in rat on
AgNORs region is as shown in (Fig. $17 \mathrm{D}$ and E). Ginger oleoresin treatment reduced the region of AgNOR. It also reduces the cell proliferation. Thus higher dose i.e. $600 \mathrm{mg} / \mathrm{kg}$ ginger oleoresin lessens the AgNOR region and the irregularity of AgNORs when compared to $300 \mathrm{mg} / \mathrm{kg}$ ginger oleoresin dose. Silymarin being standard hepatoprotective drug showed histological changes near to normal (Fig. 17C).

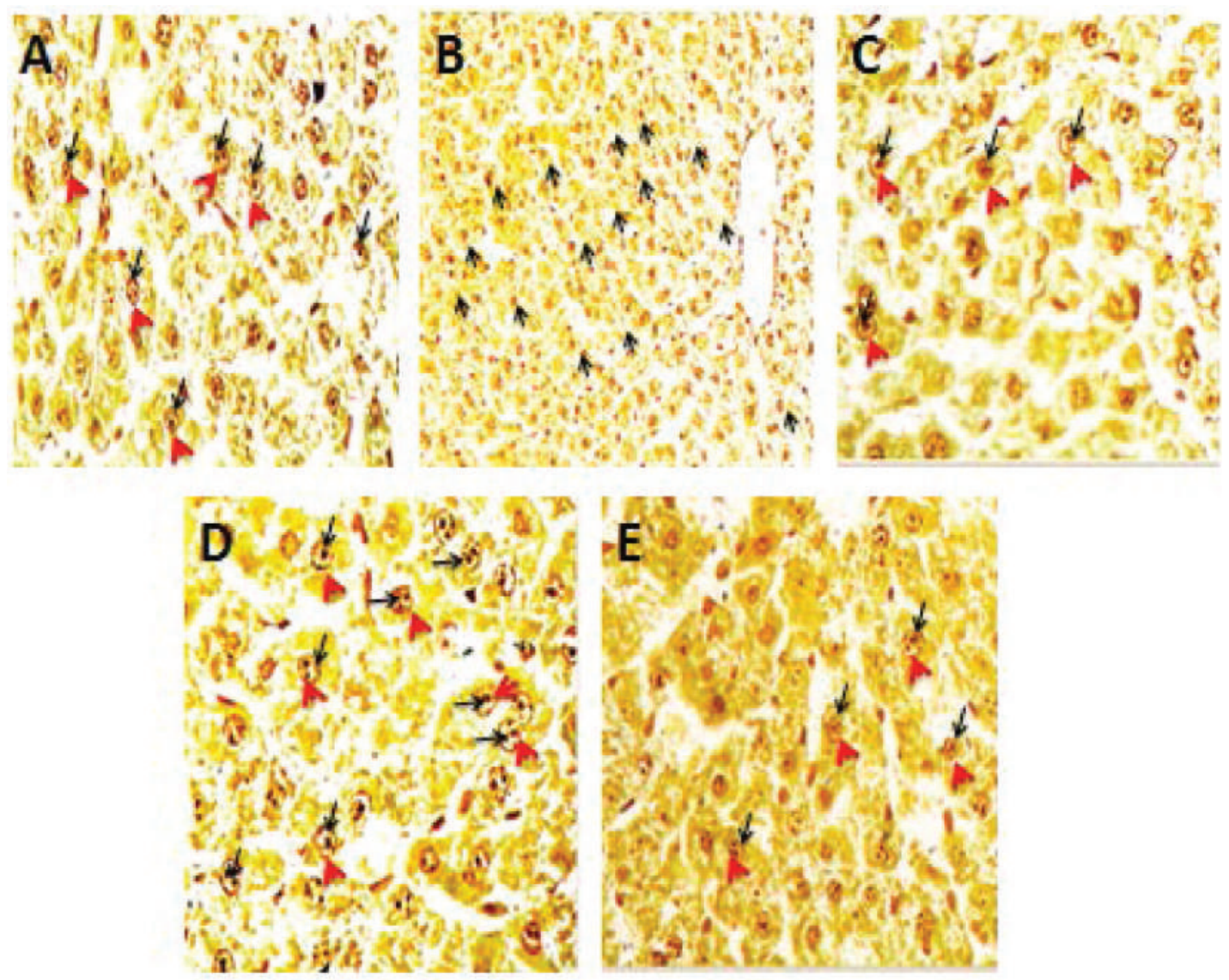

Figure 17: Effect of Ginger oleoresin on AgNORs Count.

(A) Group I (Normal group): Normal hepatic cells with nucleus $(\rightarrow$ ) and AgNOR $(\rightarrow)$

(B) Group II ( $\mathrm{CCl}_{4}$-treated group): Proliferation of cells and increase AgNORs region (dark spots)

(C) Group III $\left(\mathrm{CCl}_{4}+100 \mathrm{mg} / \mathrm{kg}\right.$ of Silymarin post treated): showing preserved hepatic nucleus and AgNOR

(D) Group IV $\left(\mathrm{CCl}_{4}+300 \mathrm{mg} / \mathrm{kg}\right.$ of Ginger oleoresin post treated group I): less marked changes

(E) Group $\mathrm{V}\left(\mathrm{CCl}_{4}+600 \mathrm{mg} / \mathrm{kg}\right.$ of Ginger oleoresin post treated group II): decrease the region of AgNORs that induced by $\mathrm{CCl}_{4}$ 


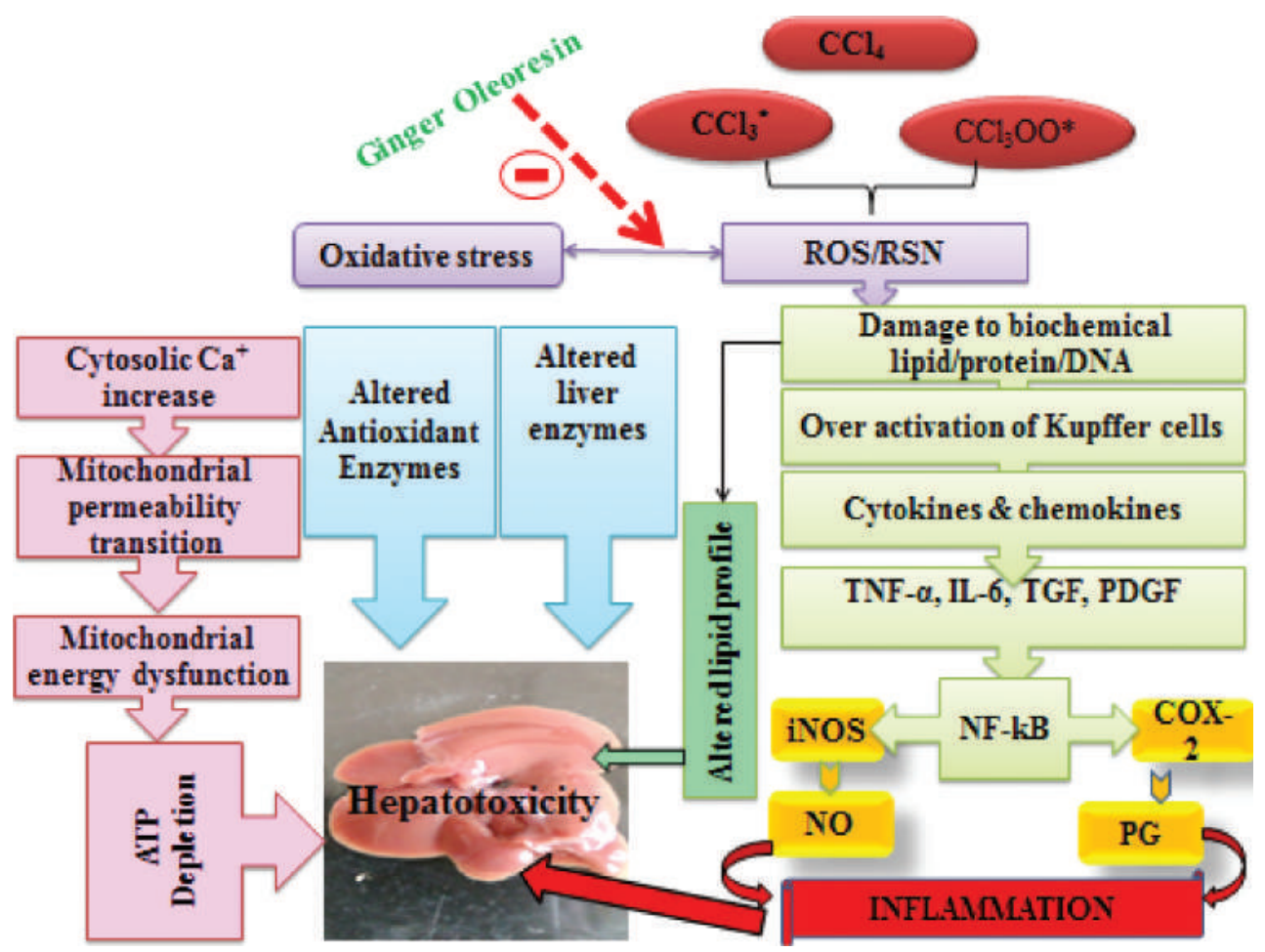

Figure 18 : Effect of ginger oleoresin on CCl4 induced hepatotoxicity

\section{Discussion}

Hepatotoxicity indicates damage to the cells, tissues, and structure or liver functions. Extraction of therapeutically effective agents from natural products may reduce the risk of hepatotoxicity. The present work showed the hepatoprotective effect of $300 \mathrm{mg} / \mathrm{kg}$ and $600 \mathrm{mg} / \mathrm{kg}$ ginger oleoresin administered by oral route against $\mathrm{CCl}_{4}$ induced liver injury in rats.

Currently millions of people are suffering from hepatic damage induced by alcohol, chemicals, drugs, and immune response. Metabolic activation is required for hepatotoxicants such as $\mathrm{CCl}_{4}$, nitrosamines, and polycyclic aromatic hydrocarbons, by liver CYP P450 enzymes to form reactive toxic metabolites, which resulted in liver injury in experimental animals and human(Gonzalez et al., 1988)To investigate the hepatotoxicity in animals by initating lipid Peroxidation, Liver injury induction by $\mathrm{CCl}_{4}$ is a well-known hepatotoxin or classic model used extensively.Indeed in the present study, intraperitoneal administration of $\mathrm{CCl}_{4}$ at the dose $2 \mathrm{ml} / \mathrm{kg}$ produced significant hepatic damage in rats as assessed by observing body weight, liver weight, oxidative stress and inflammatory markers, lipid profile, liver marker enzymes, genotoxicity and histological changes. Ginger oleoresin in dose dependent manner was found successful in attenuating these changes. The efficacy of ginger oleoresin might be the contributory effects of 6-gingerol, 6-shogaol and zingerone, which wielded intense hepatoprotective activity as suggested by reported studies (Flynn et al., 1986; Alqasouami et al., 2011; Hikino et al., 1985).

After $\mathrm{CCl}_{4}$ administration, severe body weight loss and liver swelling revealed hepatic damage. Decreased food intake, appetite weight loss is an indirect indication of the declining hepatic function and also increase in the liver weight of animals is attributed to the formation of nodules. In addition, apathetic condition with emaciation and the rising of liver index (liver weight as a percentage of body weight) in rats was mostly exhibited in $\mathrm{CCl}_{4}$ treated group. In present study, $\mathrm{CCl}_{4}$-treated rats showed a marked obvious decrease in body weight, increase $(\mathrm{p}<0.0001)$ in liver weight and liver index, when compared with the normal control group. However, treatment with ginger oleoresin resulted in improvement of the body weight and reduction in liver swelling as well as notable reduction in liver index $(\mathrm{p}<0.0001)$. The action might be due the bioactive ingredient 6-gingerol present in ginger oleoresin, which significantly decreased liver weight index as reported by (Tzeng et al., 2015).

Generally, $\mathrm{CCl}_{4}$ accumulated in parenchyma cells is metabolized by reductive dehalogenation through the microsomal cytochrome P450-dependent mono-oxygenase system, in the ER of hepatic cells to form trichloromethyl free radical $\left(\mathrm{CCl}_{3}^{*}\right) . \mathrm{CCl}_{3}^{*}$ which reacts rapidly with molecular oxygen to produce the trichloromethyl peroxyl 
radical $\left(\mathrm{CCl}_{3} \mathrm{O}_{2}{ }^{*}\right)$ (Weber et al., 2003; Feng et al., 2010). These radicals bind to proteins, lipids or abstract a hydrogen atom from an unsaturated lipid to initiate lipid peroxidation and thus liver damage, thereby contributing majorly to the pathogenesis of diseases (in fig.18)(Weber et al., 2003; Recknagel et al., 1989). Cyp2E1capacity to generate ROS and lipid peroxides it playsan vital role in the pathogenesis of liver injury (Gumieniczek, 2005).

Harmful modifications in DNA and proteins are the result of productsobtained from phase 1 reaction due electrophilic and highly reactive nature. Total protein is a common laboratory test to evaluate the effect of various toxic chemicals. Decrease in total protein content can be deemed as a useful index of severity of hepatocellular damage (Nevin and Vijayammal, 2005). The lowered level of total protein in the liver of $\mathrm{CCl}_{4}$ treated rats revealed the severity of hepatopathy, which was in agreement with our study.(Taniyama and Griendling, 2003) Post treatment with ginger oleoresin at dose dependent manner increases the level of total protein. Stimulation of protein synthesis has been advanced as a contributory self-healing mechanism, which accelerates liver regeneration process, i.e. the production of liver cells (Rip et al., 1985; Tadeusz et al., 2001). Oxidative stress associated with increase in the formation of TBARS is indicative of lipid peroxidation. Oxidative stress has been adduced to be a crucial step in $\mathrm{CCl}_{4}$ toxicity. $\mathrm{CCl}_{3} \mathrm{OO}^{*}$ is far more likely than $\mathrm{CCl}_{3}^{*}$ to abstract a hydrogen from polyunsaturated fatty acids (PUFA)(Janero, 1990), thereby initiating the process of lipid peroxidation, which caused an increase in MDA levels (Manibusan et al., 2007; Halliwell and Chirico, 1993). A major reactive aldehyde MDA appears during the peroxidation of biological membrane polyunsaturated fatty acid (Ohkawa et al., 1979; Vaca et al., 1988). The reactive species mediated hepatotoxicity with a rise in MDA level was effectively managed by administered ginger oleoresin, which possess anti-oxidant, free radical scavenger and anti-lipid peroxidant activities (Bellik, 2014; Verma et al., 1983). The effects of ginger oleoresin can be due to bioactive constitutents such as 6-gingerol, 6-shogaol and zingerone. 6-gingerol increased the expression of antioxidant enzyme by free radical scavenging, lipid peroxidation inhibition, DNA protection and reducing power abilities indicating strong antioxidant properties (Singh et al., 2009; Siddaraju and Dharmesh, 2007). 6-Shogoal was comparatively more significant in decreasing the hepatic MDA than 6 gingerol possibly due to its dominant antioxidant property(Dugasani et al., 2010). Zingerone pretreatment significantly lowered the radiation-induced lipid peroxidation in terms of MDA production (Reddy and Lokesh, 1992).

MDA increased level in the liver of $\mathrm{CCl}_{4}$-treated rats, further suggests thatto scavenge excessive free radicals, natural antioxidant defense mechanism has been
compromised(Joseph et al., 2014; Suresh and MIshra, 2008). Therefore, ROS affects the antioxidant defense mechanisms, reduced GSH, NADPH and antioxidant enzymes such as SOD, CAT. GR promotes the NADPH-dependent reduction of GSSG to GSH(Maritim et al., 2003). Free radical scavengers and chain reaction terminators, enzymes such as SOD, CAT, and GPx systems helps in defending biological systems against the damaging effects of ROS by several means, including (Proctor and McGinness, 1986; Skrzydlewska and Farbiszewski, 1997; Huang et al., 2012). Depletion of GSH pool by reactions catalysed by phase 2 enzymes, which promote the conjugation of phase 1 products with various hydrophilic moieties such as GSH and glucuronic acid initiated hepatic necrosis (Williams and Burk, 1990; Kobayashi and Yamamoto, 2006). $\mathrm{CCl}_{4}$ led to significantreduction in the levels of GSH and NADPH, and in the activity of the GR (Moreira et al., 2014). SOD and CATboth enzymatic antioxidant systems play a vital role in protection against the unwanted effects of lipid peroxidation andhydrogen peroxide in diseases related to oxidative stress (Webb and Twedt, 2008; Zhu et al., 2012). It is well documented that the disturbance of the prooxidant/ antioxidant balance induced by $\mathrm{CCl}_{4}$ is attributed to the massive amount of reactive free radicals generated during its metabolism.In present study results obtained were in agreement with above studies that treatment with $\mathrm{CCl}_{4}$ reduced the level of NADPH, SOD, CAT and GSH in hepatic tissue (fig.18). Post treatment with ginger oleoresin protected the liver from damage in dose dependent manner by significantly increasing the hepatic content of NADPH, SOD, CAT and GSH. The action of ginger oleoresin was might be due to 6-gingerol and zingerone. 6-gingerol reduced blood sugar and ease oxidative stress due to stimulation of SOD, CAT, GPx and GSH antioxidant activities (Chakraborty et al., 2012; Dugasani et al., 2010). Zingerone that inhibited the decline in stable component of ginger oleoresin which increase the intracellular antioxidant enzyme levels viz., SOD, CAT, GSH and GST (Kumar et al., 2014; Shin et al., 2005).

Hepatotoxicity induced by $\mathrm{CCl}_{4}$ lead to disruption of calcium homeostasis. $\mathrm{CCl}_{4}$-intoxicated livers were found to have increased $\mathrm{Ca}^{2+}$ content and ROS production. Impaired calcium homeostasis activate many membrane damaging enzymes, like ATPases, phospholipases, proteases and endonuclease, and disruption of mitochondrial metabolism, decreased ATP synthesis and damage of micro-filaments that support cell structure (Deepa et al., 2013; Hemmings et al., 2002). Continued $\mathrm{CCl}_{4}$ exposure, led to depletion in ATP supply and inactivates plasma membrane $\mathrm{Na}+, \mathrm{K}+$ and $\mathrm{Ca}^{2+}$ ATPase activities; as $\mathrm{Ca}^{2+}$ rushes into the cell from outside, cytosolic concentrations rise in an uncontrolled manner (Fig.18). The involvement of microsomal $\mathrm{Ca}^{2+}$ - 
ATPase in the regulation of cytosolic $\mathrm{Ca}^{2+}$ concentration and hormonal mechanisms is interconnected to other biochemical pathways responsible for the physiological well-being of the organisms. Therefore, reduction of $\mathrm{Ca}^{2+}$ ATPase activity in the present study by ginger oleoresin in dose dependent manner was highly significant, crucial and critical in preventing cytosolic calcium overload, alteration of calcium homeostasis and ultimately mitochondrialmediated cell death inducible by $\mathrm{CCl}_{4}$ toxicity.

Inflammatory processes contribute to a number of pathological events after exposure to various hepatotoxins as liver is a major inflammatory organ. Activation of Kupffer cells, the resident macrophages of liver by $\mathrm{CCl}_{4}$, release pro-inflammatory cytokines such as $\mathrm{TNF} \alpha, \mathrm{NO}$, TGF- 3 , and CRP, IL-1, IL-6, and IL-10 (Mohamed et al., 2014; Badger et al., 1996).TNF- $\alpha$ accelerates the release of cytokines from other macrophages and induces a phagocyte oxidative metabolism and NO production (Morio et al., 2001; Leist et al., 1995). NO can exacerbate oxidative stress by reacting with ROS, particularly with the superoxide anion, and cause the formation of peroxynitrite. Moreover, overproduction of $\mathrm{NO}$ by iNOS may mediate $\mathrm{CCl}_{4}$ induced acute hepatotoxicity through up-regulation of inflammatory responses (Li and Billiar, 1999). Inflammatory factorsgeneration is associated with NF- $\mathrm{BB}$ pathway in $\mathrm{CCl}_{4}$-induced acute liver injury (Fig.18). In present study, administration of $\mathrm{CCl}_{4}$ significantly caused increase in nitrite/nitrate level and CRP level, characterizing massive nitrosative stress due to hepato intoxication. However using ginger oleoresin dose dependently on lab animals with $\mathrm{CCl}_{4}-$ induced hepatopathy determined a decrease in nitrate/nitrite and CRP levels, suggesting a suppression of inflammatory response. Anti-inflammatory action observed by ginger oleoresin might be due to 6-Gingerol and 6-Shogaol which have been reported to inhibit NO production and reduce iNOS. 6-Gingerol scavenges peroxynitrite-derived radicals and inhibits peroxynitrite-induced oxidation and nitration reactions(Ippoushi et al., 2005). 6-shogaol has been reported to inhibit inflammation in diclofenac induced hepatotoxicity (Flynn et al., 1986; Pan et al., 2008; Mascolo et al., 1989).

Significant increase of lipid profile indicated a severe lipid peroxidation and physiological damage to organs after administering $\mathrm{CCl}_{4} \cdot \mathrm{CCl}_{4}$ increases denovo synthesis of fatty acids and triglycerides from acetate and also the rate of lipid esterification (Boll et al., 2001). Andriţoiu et al., showed that an increase of the parameters of the lipid profile was observed in the animals with $\mathrm{CCl}_{4}$-induced hepatopathy, concerning total cholesterol, triglycerides, VLDL and also lowering HDL. ${ }^{12}$ Similarly the present study also showed, an increase of the parameters of the lipid profile was observed in the animals induced with $\mathrm{CCl}_{4}$. There was significant increase in the cholesterol and triglyceride levels, whereas HDL was reduced due to hepatic injuries caused by their free radicals. Treatment with ginger oleoresin determined a regulation of these parameters. Increased HDL, decreased triglycerides and cholesterol levels were noticed in lab animals. Post treatment with $600 \mathrm{mg} / \mathrm{kg}$ dose of ginger oleoresin was of more potential. Again the action might be due to its active constituent 6-gingerol 6-gingerol significantly decreased liver weight index and restored the levels of triglycerides, total cholesterol and free fatty acid in the plasma and livers which may be the primary protective mechanism exerted by the compound in high fat diet fed hamsters (Tzeng et al., 2015).

Increased serum levels of ALT, AST and ALP in livers induced with $\mathrm{CCl}_{4}$ toxicity is an indication of damaged structural and functional integrity of the liver cell membranes since, these cytosolic enzymes are only released into circulation after hepatic cellular damage (Zhou et al., 2010). $\mathrm{CCl}_{4}$ could result in defective excretion of bile by hepatocytes and so increased ALP levels could reflect a pathological alteration in biliary flow (Rajesh and Latha, 2004). In this study, a significant increase in serum ALT, AST and ALP activity was observed after $\mathrm{CCl}_{4}$ administration. However, the serum ALT, AST and ALP activities significantly declined by treatment with ginger oleoresin in dose dependent manner and silymarin, implying that the ginger oleoresin can rise up stabilization of plasma membrane and ameliorate biliary dysfunction effectively there by preserving the structural integrity of cells. Again the contribution of 6-Shogoal and 6- gingerol cannot be ruled out as 6-Gingerol-rich fraction help in restoring the biomarkers ALT, AST, ALP, and GGT, sensitive indicators of hepatocellular damage and dysfunction (Salihu et al., 2016; Sabina et al., 2011), whereas 6-Shogoal, exhibited a significant hepatoprotective activity by reducing serum activities of AST, ALT and ALP, when compared to diclofenac sodium intoxicated rats(Alqasouami et al., 2011).

Histopathology is an important clinical standard for the diagnosis of hepatic damage. Thus, $\mathrm{CCl}_{4}$-treatment caused massive histopathological changes such as necrosis, fatty degeneration, inflammatory cells infilteration and hydropic ballooning (Moreira et al., 2014; Al-Sayed et al., 2014). Biochemical improvements after ginger oleoresin treatment were paralleled by histopathological findings. According to microscopic examinations, severe liver damage induced by $\mathrm{CCl}_{4}$ was markedly reduced by the administration of ginger oleoresin, which was good correlation with the results of serum enzymes activities, hepatic antioxidant enzyme activities, anti-inflammatory activities, hypolipidemic and hepatic lipid peroxidation. It was evident from the absence of cellular necrosis, hydropic ballooning, fatty degeneration and inflammatory cells infilteration, normalization of 
cellular structures in the liver section of treatment doses especially in $600 \mathrm{mg} / \mathrm{kg}$ post treated group. Silymarin drug at the dose of $100 \mathrm{mg} / \mathrm{kg}$; p.o. for 14 days produced significant histological changes in rat liver. Present results suggest that the activities of ginger oleoresin were responsible for the normalization of hepatic function at the biochemical and structural level. Silymarin, an established antihepatotoxic drug at the dose of $300 \mathrm{mg} / \mathrm{kg}$; p.o. for 14 days produced significant biochemical and histological changes.

\section{Conclusion}

Present study demonstrated that hepatoprotective effects of ginger oleoresin dueto its ability to reduce the rate of lipid peroxidation, increased antioxidant defense status, anti-inflammatory, hypolipidemic activity and to guard against the pathological changes of the liver induced by $\mathrm{CCl}_{4}$ intoxication. The hepatoprotective activity of Ginger oleoresin is concluded to be partly mediated by its active constituent's 6-gingerol, shogaol and zingerone which showed superior effect on boosting the antioxidant capacity, anti-inflammatory and hypolipidemic activity. Thus the study demonstrated experimental evidences and clearly justifies the traditional claims and use of Ginger oleoresin in the treatment of liver diseases.

\section{Conflict of Interest}

The authors declare no potential conflict of interest.

\section{References}

[1] Abenavoli, L. Capasso, R. Milic, N. Capasso, F. (2010). Milk thistle in liver diseases: past, present, future. Phytother Res. 24, 1423-1432. https://doi.org/10.1002/ptr.3207

[2] Aebi, H. (1974). Catalase in vítro. Methods Enzymol 2, 673-678.

[3] Al-Harbi, N. O. Imama, F. Nadeema, A. M. M. Al-Harbi, Iqbal, M. Ahmad S. F. (2014). Carbon tetrachloride-induced hepatotoxicity in rat is reversed by treatment with riboflavin. International Immunopharmacology. 21, 383-388.

https://doi.org/10.1016/j.intimp.2014.05.014

[4] Alkreathy, H. M. Khan, R. A. Khan, M. R. Sahreen, S. S. (2014). $\mathrm{CCl}_{4}$ induced genotoxicity and DNA oxidative damages in rats: hepatoprotective effect of Sonchus arvensis. BMC Complementary Altern Medi. 14, 1-7. https://doi.org/10.1186/1472-6882-14-1

[5] Alqasouami, S. Yusufolgu, H. Farraj, A. Alam, A. (2011). Effect of 6-Shogaol and 6-Gingerol on
Diclofenac Sodium Indued Liver Injury. International Journal of Pharmacology 7, 868-873. https://doi.org/10.3923/ijp.2011.868.873

[6] Al-Sayed, E. Martiskainen, O. Seif el-Din, H. S. AbdelNasser, A. Hammam, O. A. El-Lakkany, N. M. (2014). Hepatoprotective and Antioxidant Effect of Bauhinia hookeri Extract against Carbon Tetrachloride-Induced Hepatotoxicity in Mice and Characterization of Its Bioactive Compounds by HPLC-PDA-ESI-MS/MS. BioMed Research International 24, 1-9. https://doi.org/10.1155/2014/245171 https://doi.org/10.1155/2014/146769

[7] Andritoiu, C. V. Andritoiu, V. Cuciureanu, M. Nica-Badea, D. Bibire, N. Popa, M. (2014). Effect of apitherapy products against carbon tetrachloride induced toxicity in Wistar rats. Rom J Morphol Embryol 55, 835-847.

[8] Badger, D. A. Sauer, J. M. Hoglen, N. C. Jolley, C. S. Sipes, I. G. (1996). The role of inflammatory cells and cytochrome $\mathrm{P} 450$ in the potentiation of $\mathrm{CCl}_{4}$-induced liver injury by a single dose of retinol. Toxicol Appl Pharmacol 141, 507-519

https://doi.org/10.1006/taap.1996.0316

[9] Bandoniene, D. Gruzdiene, D. Venskutonis, P. R. Murkovic, M. (2002). Antioxidative activity of sage (Saliva officinale L.), savory (Satureja hortensis L.) and borage (Borago officinalis L.) extracts in rapeseed oil. Eur J Lipid Sci Technol 104, 286-292.

https://doi.org/10.1002/1438-9312(200205)104:5<286::AID-EJLT286>3.0.CO;2-O

[10] Basiglio, C. L. Pozzi, S. Mottino, E. J. Roma, M. G. (2009). Differential effects of silymarin and its active component silibinin on plasma membrane stability and hepatocellular lysis. Chem Biol Interact 179, 297-303. https://doi.org/10.1016/j.cbi.2008.12.008

[11] Bataller, R. and Brenner, D. A. (2005). Liver fibrosis. J Clin Invest. 115, 209-18.

[12] Bellik, Y. Y. (2014). Total antioxidant activity and antimicrobial potency of the essential oil and oleoresin of Zingiber officinale Roscoe. Asian Pac J Trop Dis 4, 40-44.

https://doi.org/10.1016/S2222-1808(14)60311-X https://doi.org/10.1016/S2221-1691(14)60206-9

[13] Boll, M. Weber, L.W. Becker, E. Stampfl, A. (2001). Pathogenesis of carbon tetrachloride-induced hepatocyte injury. Bioactivation of $\mathrm{CCl}_{4}$ by cytochrome P450 and effects on lipid homeostasis. Z Naturforsch 56, 111-121.

https://doi.org/10.1515/znc-2001-1-218

https://doi.org/10.1515/znb-2001-0201 
[14] Boll, M. Weber, L.W. D. Becker, E. Stampfl A., (2001a). Hepatocyte damage induced by carbon tetrachloride: inhibited lipoprotein secretion and changed lipoprotein composition. Z Naturforsch 56, 283-290. https://doi.org/10.1515/znc-2001-3-419

[15] Bose, P. D. Sarma, M. P. Medhi, S. Das, B. C. Sain, H. Kar, P. (2011). Role of polymorphic N-acetyl transferase2 and cytochrome P4502E1 gene in antituberculosis treatment-induced hepatitis. J Gastroenterol Hepatol 26, 312-318. https://doi.org/10.1111/j.1440-1746.2010.06355.x

[16] Chakraborty, D. Mukherjee, M. Sikdar, S. Paul, A. Ghosh, S. Khuda-Bukhsh, A. R. (2012). Toxicol Lett 210, 34-43.

https://doi.org/10.1016/j.toxlet.2012.01.002

[17] Deepa, K. I. Mandlikb, S. K. Naika, S. R. (2013). Models of hepatotoxicity and the underlying cellular, biochemical and immunological mechanism(s): A critical discussion. Environmental toxicology and pharmacology 37, 118-133.

[18] Deline, G. D. (1985). Ginger. Cereal Foods World 30, 697-699.

[19] Domenicali, M. Caraceni, P. Giannone, F. Baldassarre, M. Lucchetti, G. Quarta C. et al., (2009). A novel model of $\mathrm{CCl}_{4}$-induced cirrhosis with ascites in the mouse. J Hepatol 51, 991-999.

https://doi.org/10.1016/j.jhep.2009.09.008

[20] Dugasani, S. Pichika, M. R. Nadarajah, V. D. Balijepalli, M. K. Tandra, S. Korlakunta, J. N. (2010). Comparative Antioxidant and Anti-inflammatory Effects of [6]-Gingerol, [8]-Gingerol, [10] - Gingerol and [6]-Shogaol. J Ethnopharmacol 127, 515-520. https://doi.org/10.1016/j.jep.2009.10.004

[21] Fahmy, S. R. Hamdi, S. A. Abdel-Salam, H. A. (2009). Curative effect of dietary freshwater and marine crustacean extracts on carbon tetrachloride-induced nephrotoxicity. Aust J Basic Appl Sci 3, 2118-2129.

[22] Feng, Y. Siu, K. Y. Ye, X. Wang, N. Yuen, M. F. Leung, C. H. Tong, Y. Kobayashi, S. (2010). Hepatoprotective effects of berberine on carbon tetrachloride-induced acute hepatotoxicity in rats. Chin Med 5, 33. https://doi.org/10.1186/1749-8546-5-33

[23] Ferlay, J. Shin, H. R. Bray, F. Forman, D. Mathers, C. Parkin, D. M. (2010). Estimates of worldwide burden of cancer in 2008: GLOBOCAN. Int J Cancer. 127, 2893-2917.

[24] Flynn, D. L. Rafferty, M. F. Boctor, A. M. (1986). Inhibition of neutrophil 5-lipoxigenase activity by gingerdione, shogaol, capsaicin and related pungent compounds. Prostaglandin Leukot Med 24, 195-198. https://doi.org/10.1016/0262-1746(86)90126-5
[25] Girish, C. Pradhan, S. C. (2012). Hepatoprotective activities of picrolivcurcumin and ellagic acid compared to silymarin on carbontetrachloride-induced liver toxicity in mice. J Pharmacol Pharmacother 3, 149-155.

[26] Gonzalez, F. J. (1988). The molecular biology of cytochrome P450s. Pharmacol Rev 40, 243-288.

[27] Graupeara, M. Garcia-Pegan, J. C. Titos, E. Claria, J. Massaguer, A. Bosch, J. (2002). 5-lipoxigenase inhibiting reduces intrahepatic vascular resistance of cirrhotic rat liver: A possible role of cysteinylleukotrienes. Gastroenterol 122, 387-393. https://doi.org/10.1053/gast.2002.31040

[28] Green, L. C. Wagner, D. A. Glogowski, J. Skipper, P. L. Wishnok, J. S. Tannenbaum, S. R. (1982). Analysis of nitrate, nitrite, and $[15 \mathrm{~N}]$ nitrate in biological fluids. Anal Biochem 126, 131-138. https://doi.org/10.1016/0003-2697(82)90118-X

[29] Gumieniczek, A. (2005). Effects of repaglinide on oxidative stress in tissues of diabetic rabbits. Diab Res Clin Pract 68, 89-95. https://doi.org/10.1016/j.diabres.2004.09.018

[30] Halliwell, B. Chirico, S. (1993). Lipid peroxidation: its mechanism, measurement, and significance. Am J Clin Nutr 57, 715-724. https://doi.org/10.1093/ajcn/57.5.715S

[31] Harimurtia, N. Nhestriciab, N. Subardjo, S. Y. Yuliania, S. (2011). Effect of oleoresin concentration and composition of encapsulating materials on properties of the microencapsulated ginger oleoresin using spray drying method. Indonesian journal of agriculture 4, 33-39.

[32] Hemmings, S. J. Pulga, V. B. Tran, S.T. Uwiera, R. E. (2002). Cell Biochem Funct 20, 47-59. https://doi.org/10.1002/cbf.934

[33] Hikino, H. Kiso, Y. Kato, N. Hamada, Y. Shioirietal, T. (1985). Antihepatotoxic actions if gingerols and diarylheptanoids. J Ethanopharmacol 14, 31-39. https://doi.org/10.1016/0378-8741(85)90092-3 https://doi.org/10.1016/0378-8741(85)90025-X

[34] Huang, J. He, B. Ban, X. (2012). J. Tian, L. Zhu, Y. Wang, J Ethnopharmacol 141, 104-110. https://doi.org/10.1016/j.jep.2012.02.006

[35] Huetal, R. (2012). 6-Shogaol induces apoptosis in human hepatocellular carcinoma cells and exhibits anti-tumor activity in vivo through endoplasmic reticulum stress. PLoS One 7, 1-10. https://doi.org/10.1371/journal.pone.0046550

[36] Ippoushi, K. Ito, H. Horie, H. Azuma, K. (2005). Planta Med 71, 563-566. https://doi.org/10.1055/s-2005-864160

[37] Jadon, A. Bhadauria, M. Shukla, S. (2007) J Ethnopharmacol 109, 214-218. https://doi.org/10.1016/j.jep.2006.07.033 
[38] Janero, D. R. (1990). Malondialdehyde and thiobarbituric acid-reactivity as diagnostic indices of lipid peroxidation and peroxidative tissue injury. Free Radic Biol Med 9, 515-540. https://doi.org/10.1016/0891-5849(90)90131-2

[39] Jollow, D. J. Mitchell, J. R. Zampaglione, N. Gillete, J. R. (1974). Pharmacology 11, 151-169. https://doi.org/10.1159/000136485

[40] Joseph, J. A. Ayyappan, U. P. Sasidharan, S. R. Mutyala, S. Goudar, K. S. Agarwal, A. (2014). Pharmacognosy Res 6, 320-325. https://doi.org/10.4103/0974-8490.138284

[41] Khan, R. A. Ahmed, D. (2009). . Protective effects of Digera muricata (L.) Mart. on testis against oxidative stress of carbon tetrachloride in rat. Food Chem Toxicol 47, 1393-1399. https://doi.org/10.1016/j.fct.2009.03.020

[42] Khanna, A. K. Ansari, M. A. Kumar, M. Khanna, A. (2003). Correlation between AgNOR quantity in needle biopsy specimens of prostatic adenocarcinomas: correlation with proliferation state, Gleason score, clinical stage, and DNA content. Clin Mol Pathol 49, 209-213.

[43] Kim, S. H. Cheon, H. J. Yun, N. Oh, S. T. Shin, E. Shim, K. S. Lee, S. M. (2009). Protective effect of a mixture of Aloe vera and Silybum marianum against carbon tetrachloride-induced acute hepatotoxicity and liver fibrosis. J Pharm Sci 109, 119-127.

https://doi.org/10.1254/jphs.08299FP https://doi. org/10.1254/jphs.08189FP

https://doi.org/10.1254/jphs.08067SC

[44] Kobayashi, M. Yamamoto, M. (2006). Adv Enzyme Regul 42, 113-140. https://doi.org/10.1016/j.advenzreg.2006.01.007

[45] Kumar, L. Chhibber, S. Harjai, K. (2014). Zingerone suppresses liver inflammation induced by antibiotic mediated endotoxemia through down regulating hepatic mRNA expression of inflammatory markers in Pseudomonas aeruginosa peritonitis mouse model. PLoS One 9, 1-8.

[46] Kyung, K. S. Gon, J. H. Geun, K. Y. Sup, J. J. Suk, W. J. Ho, K. J. (2006). 6-Shogaol, a natural product, reduces cell death and restores motor function in rat spinal cord injury. Eur J Neurosci. 24, 1042-52.

[47] Larson, A. M. Polson, J. Fontana, R. J. Davern, T. J. Lalani, E. Hynan L. S. et al., (2005). Acetaminopheninduced acute liver failure: results of a United States multicenter, prospective study. Hepatology 42, 1364-1372. https://doi.org/10.1002/hep.20948

[48] Leist, M. Gantner, F. Jilg, S. Wendel, A. (1995) J Immunol 154,1307-1316.

[49] Li, J. Billiar, T. R. (1999). Am J Physiol 276, G10691073.

https://doi.org/10.1152/ajpcell.1999.276.5.C1069
[50] Lieber, C. S. Leo, M. A. Cao, Q. Ren, C. DeCarli, L. M. (2003). Silymarin retards the progression of alcohol-induced hepatic fibrosis in baboons. J Clin Gastroenterol 37, 336-339.

https://doi.org/10.1097/00004836-20031000000013

[51] Luper, S. (1998). A review of plants used in the treatment of liver disease: Part 1. Altern Med Rev 3, 410-421.

[52] Manibusan, M. K. Odin, M. Eastmond, D. A. (2007). Postulated carbon tetrachloride mode of action: a review. J Environ Sci Health C Environ Carcinog Ecotoxicol Rev 25, 185-209. https://doi.org/10.1080/10590500701569398

[53] Maritim, A. C. Sanders, R. A. Watkins, J. B. (2003). Effects of lipoic acid on biomarkers of oxidative stress in streptozotocin-induced diabetic rats. J Nutr Biochem 14, 288-294. https://doi.org/10.1016/S0955-2863(03)00036-6

[54] Mascolo, N. Jain, R. Jain, S. C. Capasso, F. (1989) J Ethnopharmacol 27, 129-140. https://doi.org/10.1016/0378-8741(89)90085-8

[55] Misra, H. P. Fridovich, I. (1972). J Biol Chem 247, 3170-3175.

[56] Mohamed, N. Z. Abd-Alla, H. I. Hanan, F. A. Mantawy, M. Ibrahim, N. Hassan, S. A. (2014). $\mathrm{CCl}_{4}$-induced hepatonephrotoxicity: protective effect of nutraceuticals on inflammatory factors and antioxidative status in rat. Journal of Applied Pharmaceutical Science 2, 87-100.

[57] Mohamed, N. Z. Abd-Alla, H. I. Hanan, F. A. Mantawy, M. Ibrahim, N. Hassan, S. A. (2014). Journal of Applied Pharmaceutical Science 2, 87-100.

[58] Moreira, P. R. Maioli, M. A. Medeiros, H. C. Guelfi, M. Pereira, F. T. Mingatto, F. E. (2014). Biological Research 13, 47-49.

[59] Morio, L. A. Chiu, H. Sprowles, K. A. Zhou, P. Heck, D. E. Gordon, M. K. (2001). Laskin Toxicol Appl Pharmacol 172, 44-51.

https://doi.org/10.1006/taap.2000.9133

[60] Nevin, K. G. Vijayammal, P. L. (2005). Fitoterapia 74, 578-580. https://doi.org/10.1016/S0367-326X(03)00148-5

[61] Nicotera, P. Bellomo, G. Orrenius, S. (1990). The role of Ca2+in cell killing. Chem Res Toxicol 3, 484-494. https://doi.org/10.1021/tx00018a001

[62] Ohkawa, H. Ohishi, N. Yagi, K.(1979). Anal Biochem 95, 351-358.

[63] Pan, M. H. Hsieh, M. C. Kuo, J. M. Lai, C. S. Wu, H. Sang, S. (2008). Mol Nutr Food Res 52, 527-537. https://doi.org/10.1002/mnfr.200700157 https://doi.org/10.1002/mnfr.200700380 https://doi.org/10.1002/mnfr.200700515 
[64] Pradhan, S. C. Girish, C. (2006). Hepatoprotective herbal drug, silymarin from experimental pharmacology to clinical medicine. Indian J Med Res 124, 491-504.

[65] Proctor, P. H. McGinness, E. (1986). The function of melanin. Arch Dermatol. Arch Dermatol 122, 507-508. https://doi.org/10.1001/ archderm.1986.01660170031013 https://doi.org/10.1001/archderm.122.5.507

[66] Rajesh, M. G. and Latha M. S. (2004). Preliminary evaluation of the anti hepatotoxic activity of Kamilari, apoly herbal formulation. Preliminary evaluation of the antihepatotoxic activity of Kamilari, a poly herbal formulation. J Ethnopharmacol. 91, 99-104. https://doi.org/10.1016/j.jep.2003.12.011

[67] Ramanathan, M. Babu, C. S. Justin, A. Shanthakumari, S. (2012). J Exp Biol 50, 391-397.

[68] Recknagel, R. O. Glende, E. A. Dolak J. A. JA, R. L. Waller, R. L. (1989). Mechanisms of carbon tetrachloride toxicity. Pharmacol Ther 43, 139-154. https://doi.org/10.1016/0163-7258(89)90050-8

[69] Reddy, A. C. Lokesh, B. R. (1992). Studies on spice principles as antioxidants in the inhibition of lipid peroxidation of rat liver microsomes. Mol Cell Biochem 111, 117-124.

[70] Rip, J.W. Rupar, C. A. Ravi, K. Carroll, K. K. (1985). Distribution, metabolism and function of dolichol and polyprenols. Prog Lipid Res 24, 269-309. https://doi.org/10.1016/0163-7827(85)90008-6

[71] Sabina, E. P. Pragasam, S. J. Kumar, S. Rasool, M. (2011). 6-gingerol, an active ingredient of ginger, protects acetaminophen-induced hepatotoxicity in mice. J Chin Integr Med 9, 1264-1269. https://doi.org/10.3736/jcim20111116

[72] Sai, K. Tyson, C. A. Thomas, D. W. Dabbs, J. E. Hasegawa, R. Kurokawa, Y. (1994). Cancer Lett 87, 1-7. https://doi.org/10.1016/0304-3835(94)90402-2

[73] Salihu, M. Ajayi, B. O. Adedara, I. A. Farombi, E. O. (2016). 6-Gingerol-Rich Fraction from Zingiber officinale Prevents Hepatotoxicity and Oxidative Damage in Kidney and Liver of Rats Exposed to Carbendazim. Journal of Dietary Supplements 1, 1-16.

[74] Shin, S. G. Kim, J. Y. Chung, H. Y. Jeong, J. C. (2005). Zingerone as an antioxidant against peroxynitrite. J Agric Food Chem 53, 7617-7622. https://doi.org/10.1021/jf051014x

[75] Siddaraju, M. N. Dharmesh, S. M. (2007). Mol Nutr Food Res 51, 324-332. https://doi.org/10.1002/mnfr.200600202

[76] Singh, A. B. Singh, N. Maurya, R. Srivastava, A. K. (2009). Anti-hyperglycaemic, lipid lowering and antioxidant properties of [6]-gingerol in $\mathrm{db} / \mathrm{db}$ mice. Int $\mathrm{J}$ Med Sci 1, 536-544.
[77] Singh, G. Maurya, S. Catalan, C. de Lampasona, M. P. (2005). Studies on essential oils, Part 42: chemical, antifungal, antioxidant and sprout suppressant studies on ginger essential oil and its oleoresin. Flavour Fragr J 20, 1-6. https://doi.org/10.1002/ff.1373

[78] Skottova N., Krecman, V. Simanek, V. (1999). Activities of silymarin and its flavonolignans upon low density lipoprotein oxidizability in vitro. Phytother Res 13, 535-537.

https://doi.org/10.1002/(SICI)1099-1573(199909)13:6<535::AID-PTR526>3.0.CO;2-W

[79] Skrzydlewska, E. Farbiszewski, R. (1997). Antioxidant status of liver, erythrocytes, and blood serum of rats in acute methanol intoxication. Alcohol 14, 431-437. https://doi.org/10.1016/S0741-8329(96)00149-8

[80] Suresh, S.V. Mishra, S.H. (2008). Indian J Exp Biol 46, 447-452.

[81] Suzek, H. Celik, I. Dogan, A. Yildirim, S. (2015). Protective effect and antioxidant role of sweetgum (Liquidambar orientalis) oil against carbon tetrachloride-induced hepatotoxicity and oxidative stress in rats. Informa Healthcare 22, 1-7.

[82] Tadeusz, J. Teresa, J. Krzysztof, N. (2001). The role of polyprenol in modulation of physical properties of model membranes. Curr Top Biophys 25, 33-38.

[83] Tanaka, Y. Hanada, K. Mizokami, M. Yeom A. E. Shih, J. W. Gojobori, T. Alter, H. J. Taniyama, Y. Griendling, K. K. (2003). Reactive oxygen species in the vasculature: molecular and cellular mechanisms. Hypertension. 42, 1075-1081. https://doi. org/10.1161/01.HYP.0000100443.09293.4F

[84] Titos, E., Claria, J. Planguma, A. Lopez-Parra, M. Gonzalez-Periz, A. (2005). Inhibition of 5-lipoxigenase activating protein abrogates experimental liver injury: Role of Kupffer cells. J Leukocyte Biol 78, 871-878. https://doi.org/10.1189/jlb.1204747

[85] Trere, D. (2000). Micron 31, 127-131. https://doi.org/10.1016/S0968-4328(99)00069-4

[86] Trere, D. Zilbering, A. Dittus, D. Kim, P. Ginsberg, P. C. Daskal, I. (1996). Clin Mol Pathol 49, M209-213. https://doi.org/10.1136/mp.49.4.M209

[87] Tzeng,T. F. Liou, S. S. Chang, C. J. Liu, I. M. (2015). 6-Gingerol Protects against Nutritional Steatohepatitis by Regulating Key Genes Related to Inflammation and Lipid Metabolism. Nutrients 7, 999-1020. https://doi.org/10.3390/nu7020999 https://doi.org/10.3390/nu7105423 https://doi.org/10.3390/nu7095369

[88] Vaca, C. E. Wilhelm, J. M. Harms-Rihsdahl, M. (1988). Interaction of lipid peroxidation product with DNA. Mutat Res Rev Gen Toxicol 195, 137-149. https://doi.org/10.1016/0165-1110(88)90022-X 
[89] Verma, S. K. Singh, J. Khamesra, R. Bordia, A. (1993). Effect of ginger on platelet aggregation in man. Indian J Med Res 98, 240-242.

[90] Webb, C. Twedt, D. (2008). Oxidative stress and liver disease. Vet Clin North Am Small Anim Pract 38, $125-135$.

https://doi.org/10.1016/j.cvsm.2007.10.001

[91] Weber, L. W. Boll, M. Stampfl, A. (2003). Hepatotoxicity and mechanism of action of haloalkanes: carbon tetrachloride as a toxicological model. Crit Rev Toxicol 33, 105-136. https://doi.org/10.1080/713611034

[92] Williams, A.T. Burk, R. F. (1990). Carbontetrachloride hepatotoxicity: an example of free radical-mediated injury. Semin Liver Dis 10, 279-284.

https://doi.org/10.1055/s-2008-1040483
[93] Young, H.Y. Luo, Y. L. Cheng, H. Y. Hsieh, W. C. Liao, J. C. Peng, W. H. (2005). Analgesic and anti-inflammatory activities of [6]-gingerol. J Ethnopharmacol 96, 207-210. https://doi.org/10.1016/j.jep.2004.09.009

[94] Zhou, D. Ruan, J. Cai, Y. Xiong, Z. Fu, W. Wei, A. (2010). Antioxidant and hepatoprotective activity of ethanol extract of Arachniodeexilis (Hance) Ching. J Ethnopharmacol 129, 232-237.

https://doi.org/10.1016/j.jep.2010.03.016

[95] Zhu, R. Wang, Y. Zhang, L. Guo, Q. (2012). Oxidative stress and liver disease. Hepatol Res. Hepatol Res 42, 741-749.

https://doi.org/10.1111/j.1872-034X.2012.00996.x 